National Water Availability and Use Pilot Program

Methods and Indicators for Assessment of Regional Ground-Water Conditions in the Southwestern United States

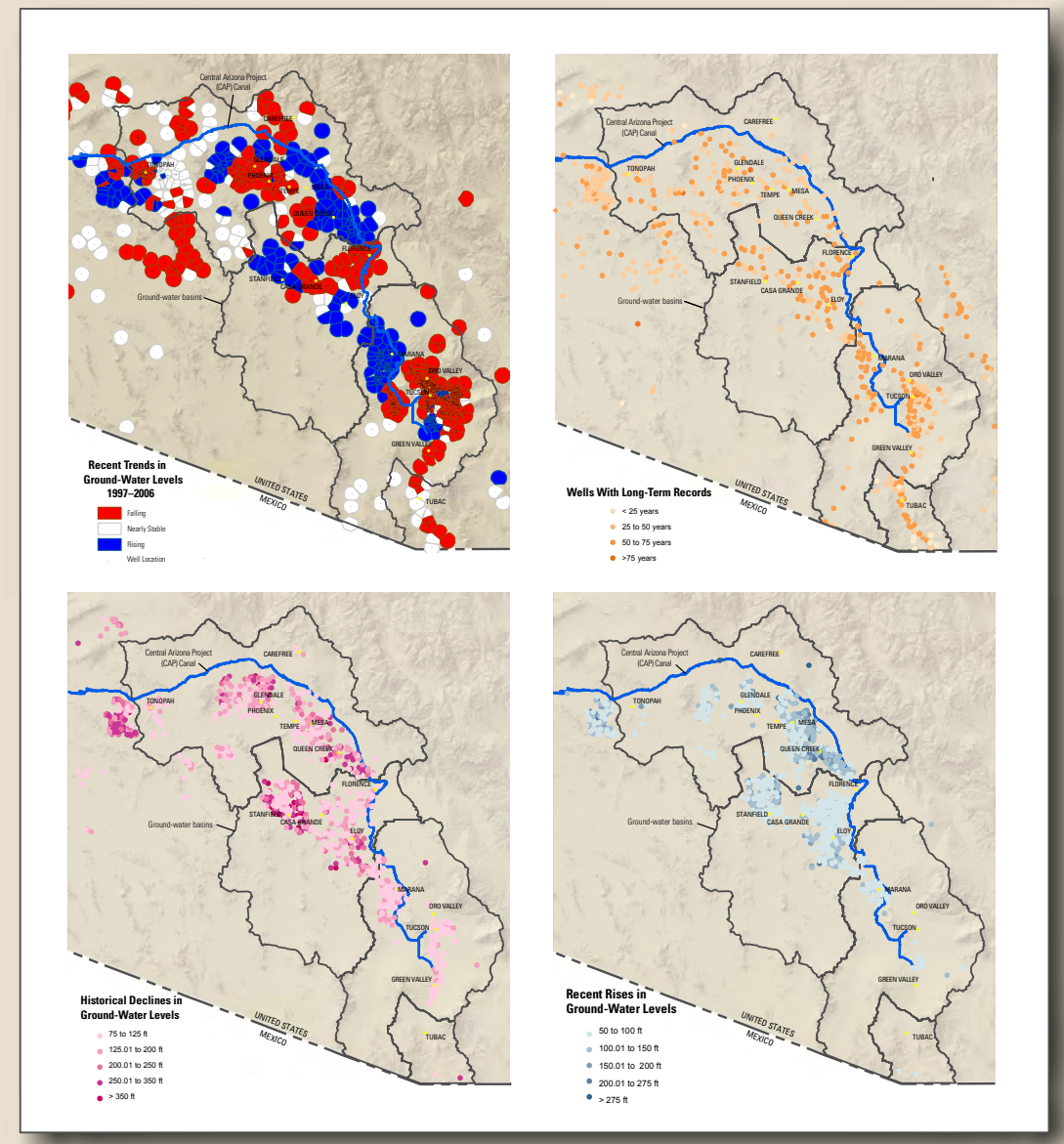

Scientific Investigations Report 2008-5209 
This page left intentionally blank. 
National Water Availability and Use Pilot Program

\section{Methods and Indicators for Assessment of Regional Ground-Water Conditions in the Southwestern United States}

By Fred D Tillman, Stanley A. Leake, Marilyn E. Flynn, Jeffrey T. Cordova, Kurt T. Schonauer, and Jesse E. Dickinson

Scientific Investigations Report 2008-5209

U.S. Department of the Interior

U.S. Geological Survey 


\section{U.S. Department of the Interior DIRK KEMPTHORNE, Secretary}

\section{U.S. Geological Survey \\ Mark D. Myers, Director}

U.S. Geological Survey, Reston, Virginia: 2008

This report and any updates to it are available online at:

http://pubs.usgs.gov/sir/2008/5209/

For product and ordering information:

World Wide Web: http://www.usgs.gov/pubprod

Telephone: 1-888-ASK-USGS

For more information on the USGS - the Federal source for science about the Earth, its natural and living resources, natural hazards, and the environment:

World Wide Web: http://www.usgs.gov

Telephone: 1-888-ASK-USGS

Any use of trade, product, or firm names is for descriptive purposes only and does not imply endorsement by the U.S. Government.

Although this report is in the public domain, permission must be secured from the individual copyright owners to reproduce any copyrighted materials contained within this report.

Suggested citation:

Tillman, F.D, Leake, S.A., Flynn, M.E., Cordova, J.T., Schonauer, K.T., and Dickinson, J.E., 2008, Methods and indicators for assessment of regional ground-water conditions in the southwestern United States: U.S. Geological Survey Scientific Investigations Report 2008-5209, 22 p. [http://pubs.usgs.gov/sir/2008/5209/]

Produced in the Western Region, Menlo Park, California Manuscript approved for publication, October 29, 2008

Text edited by Peter H. Stauffer

Layout by David R. Jones 


\section{Contents}

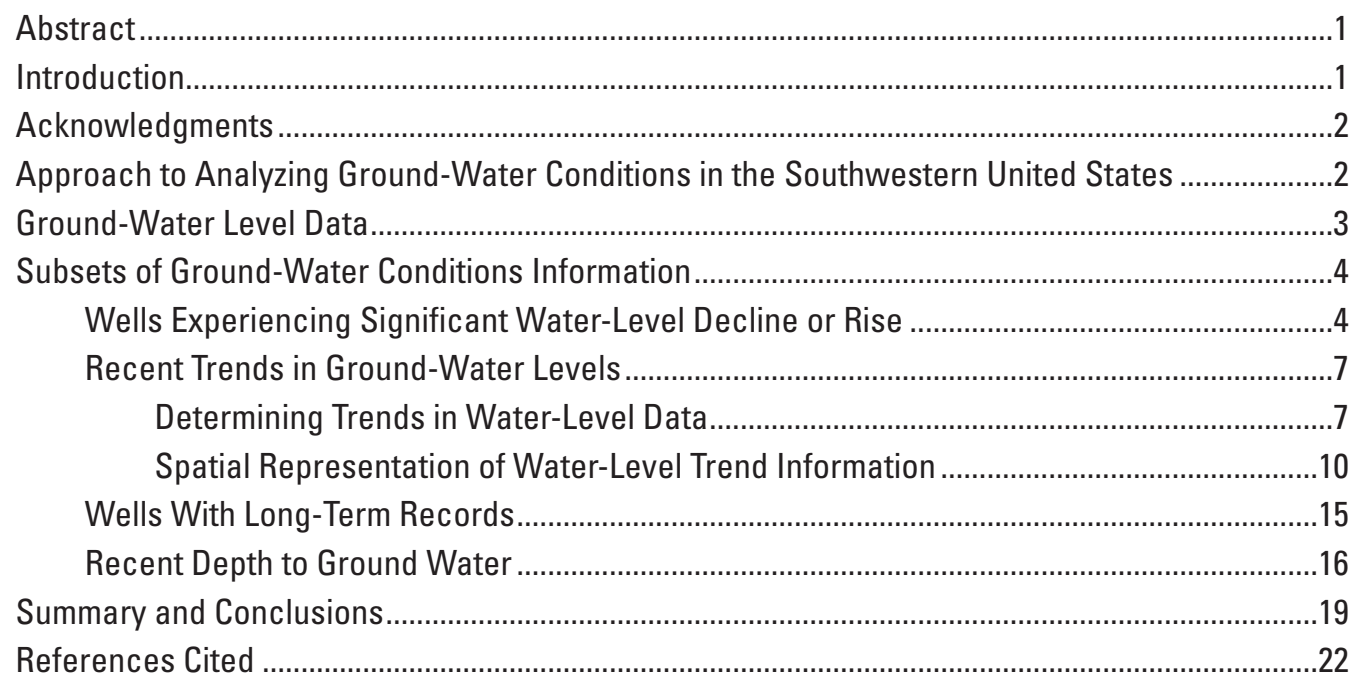

\section{Figures}

1. Schematic representation of algorithm for VBA ${ }^{\circledR}$ program that produces ground-water conditions subset of wells experiencing water-level declines and wells experiencing water-level rises

2. Examples of annotated hydrographs produced for wells experiencing water-level decline and wells experiencing water-level rise

3. Screenshot of example spreadsheet output from VBA ${ }^{\circledR}$ program summarizing wells experiencing water-level decline

4. Wells experiencing significant ground-water level decline during historical (pre-1997) time in the most developed basins of south-central Arizona ....................................8

5. Wells experiencing significant ground-water level rise continuing through recent time (post-1997) in the most developed basins of south-central Arizona .......................9

6. Schematic representation of FORTRAN algorithm for computing trends in ground-water level data

7. Examples of different subsets of water-level data during a given time period used for trend analyses

8. Screenshot of example output of trend-computation program with header indicating selection choices.

9. Annotated hydrograph produced during the recent trends in ground-water levels analysis of ground-water conditions

10. Schematic representation of FORTRAN algorithm for computing modified Thiessen polygons of selected wells for spatial representation of water-level trends ............15

11. Trends in ground-water levels for the 10-year period from 1997 through 2006 for the most developed basins in south-central Arizona.

12. Portion of example output in Microsoft ${ }^{\circledR}$ Excel $^{\circledR}$ spreadsheet of $\mathrm{VBA}^{\circledR}$ program written to provide information on time span and frequency of ground-water level observations .......18

13. Example of a hydrograph produced for the "Wells with Long-Term Records" layer of ground-water conditions

14. Wells with long-term records in the most developed basins of south-central Arizona ............20

15. Recent observations of depth to ground water (since 2004) in the most developed basins of south-central Arizona 


\section{Tables}

1. Location of well and water-level information in input spreadsheet used for all programs created to analyze and present ground-water conditions.....

2. Number of wells from example Idaho dataset with acceptable linear trends in ground-water levels for different subsets of water-level observations analyzed

\section{Conversion Factors}

\begin{tabular}{|c|c|c|}
\hline Multiply & By & To obtain \\
\hline \multicolumn{3}{|c|}{ Length } \\
\hline meter $(\mathrm{m})$ & 3.281 & foot $(\mathrm{ft})$ \\
\hline kilometer (km) & 0.6214 & mile (mi) \\
\hline \multicolumn{3}{|c|}{ Area } \\
\hline square meter $\left(\mathrm{m}^{2}\right)$ & 0.0002471 & acre \\
\hline square kilometer $\left(\mathrm{km}^{2}\right)$ & 0.3861 & square mile $\left(\mathrm{mi}^{2}\right)$ \\
\hline \multicolumn{3}{|c|}{ Flow rate } \\
\hline cubic meter per day $\left(\mathrm{m}^{3} / \mathrm{d}\right)$ & 0.0004087 & cubic foot per second $\left(\mathrm{ft}^{3} / \mathrm{s}\right)$ \\
\hline cubic meter per day $\left(\mathrm{m}^{3} / \mathrm{d}\right)$ & 264.2 & gallon per day (gal/d) \\
\hline cubic meter per day $\left(\mathrm{m}^{3} / \mathrm{d}\right)$ & 0.2961 & gallon per minute (gal/min) \\
\hline cubic meter per day $\left(\mathrm{m}^{3} / \mathrm{d}\right)$ & 0.1834 & acre-foot per year \\
\hline \multicolumn{3}{|c|}{ Recharge and evapotranspiration rate } \\
\hline meter per day $(\mathrm{m} / \mathrm{d})$ & 3.281 & foot per day (ft/d) \\
\hline \multicolumn{3}{|c|}{ Hydraulic conductivity } \\
\hline meter per day $(\mathrm{m} / \mathrm{d})$ & 3.281 & foot per day $(\mathrm{ft} / \mathrm{d})$ \\
\hline \multicolumn{3}{|c|}{ Specific storage } \\
\hline per meter $\left(\mathrm{m}^{-1}\right)$ & 0.3048 & per foot $\left(\mathrm{ft}^{-1}\right)$ \\
\hline
\end{tabular}

Vertical coordinate information is referenced to the North American Vertical Datum of 1988 (NAVD 88). Horizontal coordinate information is referenced to North American Datum of 1927 (NAD 27). Altitude, as used in this report, refers to distance above the vertical datum. 


\title{
Methods and Indicators for Assessment of Regional Ground-Water Conditions in the Southwestern United States
}

\author{
By Fred D Tillman, Stanley A. Leake, Marilyn E. Flynn, Jeffrey T. Cordova, Kurt T. Schonauer, and \\ Jesse E. Dickinson
}

\section{Abstract}

Monitoring the status and trends in the availability of the Nation's ground-water supplies is important to scientists, planners, water managers, and the general public. This is especially true in the semiarid to arid southwestern United States where rapid population growth and limited surface-water resources have led to increased use of ground-water supplies and water-level declines of several hundred feet in many aquifers. Individual well observations may only represent aquifer conditions in a limited area, and wells may be screened over single or multiple aquifers, further complicating single-well interpretations. Additionally, changes in ground-water conditions may involve time scales ranging from days to many decades, depending on the timing of recharge, soil and aquifer properties, and depth to the water table. The lack of an easily identifiable ground-water property indicative of current conditions, combined with differing time scales of water-level changes, makes the presentation of ground-water conditions a difficult task, particularly on a regional basis. One approach is to spatially present several indicators of ground-water conditions that address different time scales and attributes of the aquifer systems. This report describes several methods and indicators for presenting differing aspects of ground-water conditions using water-level observations in existing datasets. The indicators of ground-water conditions developed in this study include areas experiencing water-level decline and water-level rise, recent trends in ground-water levels, and current depth to ground water. The computer programs written to create these indicators of ground-water conditions and display them in an interactive geographic information systems (GIS) format are explained and results illustrated through analyses of ground-water conditions for selected alluvial basins in the Lower Colorado River Basin in Arizona.

\section{Introduction}

Ground water is an important resource in the southwestern United States, making up from 22 percent in Colorado to 90 percent in New Mexico of water needs for domestic use
(Anderson and Woolsey, 2005). Availability of deep-well turbine pumps and rural electricity in the mid- $20^{\text {th }}$ century allowed development of agriculture in desert basins that receive minimal rainfall. Adding additional stress to limited ground-water resources, Nevada, Arizona, Colorado, and Utah rank $1^{\text {st }}$ through $4^{\text {th }}$, respectively, in the list of fastest growing states in the United States (Anderson and Woolsey, 2005). As ground water is increasingly developed in the rapidly growing arid and semiarid southwestern United States, tools are needed to evaluate the effects of ground-water withdrawals on aquifer conditions. Knowledge of the current status of ground-water conditions is an indication of the availability of ground-water supplies. Monitoring changes in ground-water conditions allows for evaluation of the impact of growth, management actions, and climatic variations on these resources. In recent decades, nonextractive uses of ground water, such as maintaining baseflow to streams and high water levels beneath riparian vegetation, have become increasingly important and require investigation and evaluation of ground-water conditions. Earth fissures and land subsidence have occurred in some areas of the Southwest experiencing significant water-level declines and consequent aquifer compaction, adversely impacting canals and roads and leading to a loss of aquifer storage. Information on regional ground-water conditions and trends is necessary to evaluate the potential for such aquifer compaction. In 1984, the U.S. Geological Survey (USGS) published a nationwide map indicating areas of major water-level change (U.S. Geological Survey, 1984), and maps have been prepared by the USGS for select parts of the Lower Colorado River Basin and other areas of the United States (Anderson, 1995). Despite the need for better and updated information, however, no update of ground-water conditions has been completed that parallels the ongoing analysis of surface-water resources. This report describes the development of methods of assessment and display of ground-water conditions from analyses of existing information available in public databases. Several indicators of ground-water conditions, each describing a different aspect of the aquifer system, were developed. The use of these methods to present ground-water conditions is demonstrated in this report, and on a publicly available interactive Web site, using data from the most 
developed alluvial basins in Arizona (Tillman and others, 2007). Representing ground-water conditions in a broadly understandable manner presents challenges that are different from those for surface-water bodies. However, educating the public and policymakers on the status of ground-water resources is an increasingly important task in ensuring the sustainable management of this critical but largely unseen resource.

\section{Acknowledgments}

Development of methods and indicators of ground-water conditions for the alluvial basins in Arizona was funded by the USGS Water Availability and Use Program. Teri Davis and Terry Voght of the Arizona Department of Water Resources, and Bill Cunningham, Kevin Dennehy, and Tom Reilly of the USGS provided valuable technical guidance at various stages in the development of the methods and interactive map. Jeff Phillips, formerly of the USGS, was instrumental in developing ideas for presentation of data. Cheryl Partin of the USGS provided database support.

\section{Approach to Analyzing Ground-Water Conditions in the Southwestern United States}

Are there areas in my region that have experienced declining ground-water levels in the past? What areas continue to have falling water levels? Are there areas where water levels have started coming back up? What are the trends in ground-water levels over recent years? Are there wells with long-term records that may demonstrate decadal influences of changing climate and water use? What is the most recent observation of depth to ground water in my area? Each of these questions represents a potentially important spatial and temporal aspect of the condition of ground-water resources. With surface-water systems such as rivers, streams, lakes, and reservoirs, the condition of the water body is fairly straightforward to analyze and present and is easily understood by an audience with a wide range of backgrounds. Indicators of surface-water conditions such as stage, discharge, and days of water remaining can be observed on a frequent schedule and may easily be compared to historical observations to produce an indication of the current status of the system availability. River and lake levels can change rapidly due to local or upstream precipitation or management actions. Information on changes in these indicators may therefore need to be obtained on a fairly short time scale to provide water managers with information in order to manage reservoir releases, time irrigation allocations, and issue flood warnings, among other issues. The public may be interested in short-term indicators of surface-water systems in order to make decisions on waterrecreation activities such as boating, rafting, or fishing.

The frequent collection of data on ground-water levels and comparison to historical observations has been successful in understanding ground-water conditions in some areas of the United States (for example, see http://pa.water.usgs.gov potomac;; http://ma.water.usgs.gov/water/water g.htm; http:// md.water.usgs.gov/groundwater/; http://www.sflorida.er.usgs. govd; http://nh.water.usgs.gov/WaterData/2008/mar08gwmap. htm; http://groundwaterwatch.usgs.govd. Typically, for these comparisons to be a meaningful indicator of ground-water conditions, the historical observations should vary around a fairly stable average, at least on a monthly or seasonal basis. In heavily developed areas of the arid and semiarid Southwest, however, steady declines in water levels over many years, combined with infrequent water-level observations, may make comparisons to historical averages less meaningful. An investigation of ground-water conditions in the most developed alluvial basins of Arizona, for example, found nearly 1,400 wells with records indicating at least 100 feet of decline during their period of record and more than 100 wells with greater than 300 feet of decline. Additionally, groundwater levels in the Southwest may not necessarily require such frequent assessment as can be provided by real-time transducer technology, both because the lag in aquifer response to recharge/discharge can be on the order of months to decades (with the important exception of riparian areas with shallow ground-water levels) and because it is unclear what decisions and actions would necessarily be required based on such shortterm information.

Other efforts at presenting ground-water data in Arizona include Internet-based maps of index wells http://sahra. arizona.edu/wells/) and automated ground-water monitoring sites (http://arcims.azwater.gov/gwsi/Default.aspx), all with links to hydrographs of water-level data. These Web sites simply present the available well data with no attempt at explaining ground-water conditions in the area. New computer programs were developed that group data from existing databases into logical subsets, each of which tells a different part of the story of ground-water conditions. A new method for analyzing and presenting recent trends is also described in this report. These tools present ground-water information in a GIS format that allows visualization of ground-water conditions at differing temporal and spatial scales. Computer programs are described that create well hydrographs that are linked to well locations in many of the subsets. These custom hydrographs highlight pertinent observations in the waterlevel observation dataset. By presenting several interpretative indicators of ground-water conditions, each answering a different question about the ground-water system, we provide more than just water-level data and take advantage of an opportunity to inform the public and policymakers on the status and trends of ground-water conditions. 


\section{Ground-Water Level Data}

Much of the data on ground-water levels for the Nation's aquifers are held in the USGS National Water Information System (NWIS) database of each of the 48 USGS Science Centers. Public access is provided via NWISWeb to these data that are retrieved and collected from the science centers. This publicly accessible database contains real-time, daily, and other less frequent observations of ground-water levels for thousands of wells throughout the country (see http://waterdata.usgs.gov/nwis/gw). However, in some areas of the United States, other Federal, State or local governments or private industries (for example, environmental consulting firms or mining operations) may collect water levels that ultimately reside in an archive that is not electronically accessible. For example, in the State of Arizona, most of the recent waterlevel monitoring is performed by the Arizona Department of Water Resources (ADWR). The repository for ADWR waterlevel observations is its own database, called the Groundwater Site Inventory (GWSI), which is made available to the public through CD-ROM. This periodic dissemination of data precludes the type of automatic access via NWISWeb or updated Web-based products used for the USGS Ground-Water Watch (http://groundwaterwatch.usgs.gov), with the exception of the 300 or so "active" wells in the State available in NWIS, nearly half of which are located in a single Arizona county (see http:// groundwaterwatch.usgs.gov/StateMaps/AZ.html).

The presence of multiple primary sources of groundwater data presents a challenge to analyzing ground-water conditions. The first task in the present study was the development of a method to combine databases into a single dataset that may then be used by other computer programs created to analyze and display ground-water conditions. A Visual Basic for Applications $\left(\mathrm{VBA}^{\circledR}\right)$ program was developed in Microsoft ${ }^{\circledR}$ Excel $^{\circledR}$ to combine multiple ground-water datasets. While this initial step cannot be performed in real-time, batch processing of this combination of existing data and further data processing can be performed on a cycle that should be sufficient to capture most of the change in ground-water systems in a reasonable time frame. A dataset containing, at a minimum, a unique well identifier, well-location coordinates, and water-level observations and dates is required, with the location of these data in the spreadsheet specified (table 1). Additional well information, such as well depth and altitude of land surface, are useful in presenting informative hydrographs. All data from each of the datasets to be merged are first placed in a single spreadsheet, with data in predefined columns (table 1). The former limitation of Excel ${ }^{\circledR} 2003$ 's maximum of 65,536 rows of data has been greatly expanded in Excel $^{\circledR}$ 2007 , with $1,048,576$ rows of data now allowed. The $\mathrm{VBA}^{\circledR}$ program creates a new spreadsheet of the merged datasets, eliminating duplicate entries having the same site identification number, water-level observation date, and depth to ground water, and formats the remaining data for use in the other analysis programs described below. The program also elimi- nates water-level measurements from the combined dataset that are flagged as being collected during pumping conditions at the well (an entry of "P" in column I of the spreadsheet), although this function can be suppressed or additional flagged data eliminated by changing a code statement. The pumping observations were judged to not be indicative of natural ground-water conditions and were therefore not utilized in further analyses.

Subsets of information on ground-water conditions are presented in a GIS environment, several with a link from the well location to an annotated hydrograph created for the layer. $\mathrm{VBA}^{\circledR}$ programs were written to create these annotated well hydrographs for each subset of data, all of which utilize a common approach. All of the developed hydrograph-VBA ${ }^{\circledR}$ programs utilize the combined dataset spreadsheet and present all water-level observations (except observations flagged as pumping as explained above). Water levels that are observed more than one year apart are indicated with a dashed line, whereas observations occurring one year or less apart are indicated with a solid line. A common scale for date of observation and water-level depth are used for all hydrographs to aid in comparison of results between wells. Additional information is provided in the hydrograph header, including site identification number, local well name, latitude and longitude of the well location, the altitude of land surface at the well location, and the well depth (if this information is provided in the combined data spreadsheet). The date the hydrograph was created is presented in the footer area of the chart.

Table 1. Location of well and water-level information in input spreadsheet used for all programs created to analyze and present ground-water conditions.

[GWSI, Ground-Water Site Inventory; LSD, Land Surface Datum.]

\begin{tabular}{c|c|l}
\hline $\begin{array}{c}\text { Spreadsheet } \\
\text { column }\end{array}$ & $\begin{array}{c}\text { USGS GWSI } \\
\text { component number }\end{array}$ & \multicolumn{1}{c}{ Description } \\
\hline A & C004 & Source agency code \\
B & C001 & Site identification number \\
C & C012 & Station name \\
D & C009 & Latitude \\
E & C010 & Longitude \\
F & C036 & Latitude/Longitude datum \\
G & C235 & Water-level measurement date \\
H & $\mathrm{C} 237$ & Water-level below LSD \\
I & $\mathrm{C} 238$ & Water-level status \\
J & C016 & Altitude of land surface \\
K & C022 & Altitude datum \\
L & C024 & Primary use of water \\
M & C027 & Hole depth \\
N & C028 & Well depth \\
\hline
\end{tabular}




\section{Subsets of Ground-Water Conditions Information}

Unlike surface-water indicators of stage or discharge, ground water may not have a unique identifier that supplies sufficient information on aquifer conditions. Differences in response times as well as spatial limitations of individual measurements require a different approach to analyzing, presenting, and understanding ground-water conditions. Although a map showing well locations containing links to hydrographs of water-level observations is a first-order approach to present the complete set of data, much additional information can be shown to better understand ground-water conditions. Methods were developed to present ground-water conditions using subsets of existing water-level observations, with the results of each subset designed to address a different aspect of aquifer conditions. The common components of all subsets of groundwater information presented here are that the analyses are performed on a single, combined dataset in a spreadsheet with specified locations (as described above) and that all results are presented in a GIS format in a way that promotes understanding of the aspect of ground-water conditions of interest. The development of each subset of information is described and demonstrated with examples from the most developed alluvial basins in the Lower Colorado River Basin in Arizona.

\section{Wells Experiencing Significant Water-Level Decline or Rise}

Ground-water development in many areas throughout the Southwest has caused sometimes dramatic water-level declines. Some of these water-level declines may have ceased during past time periods, while others continue during recent times. Likewise, wells in some areas may have experienced rises in water levels during prior time periods, only to cease rising more recently. Other wells may still be experiencing water-level rises that continue today. Thus, an important aspect of the history of ground-water systems might be indicated by answers to questions such as: Are there areas in my region that have experienced declining ground-water levels in the past? What areas continue to have falling water levels? Are there areas where water levels have started recovering?

In an effort to discern areas with falling or rising water levels, either in the past or continuing to the present, subsets of existing water-level observations were developed for specific decline and rise criteria. Although a well may demonstrate several periods of rising and falling water levels throughout its period of record, only the maximum total decline or rise is presented in these layers. Creation of these indicators of groundwater conditions is facilitated by two VBA ${ }^{\circledR}$ programs. The first program analyzes the data record for all wells in a dataset and produces a spreadsheet of summary decline and rise information for all wells (fig. 1). The second program produces portable document format (pdf) hydrographs of wells in the spreadsheet

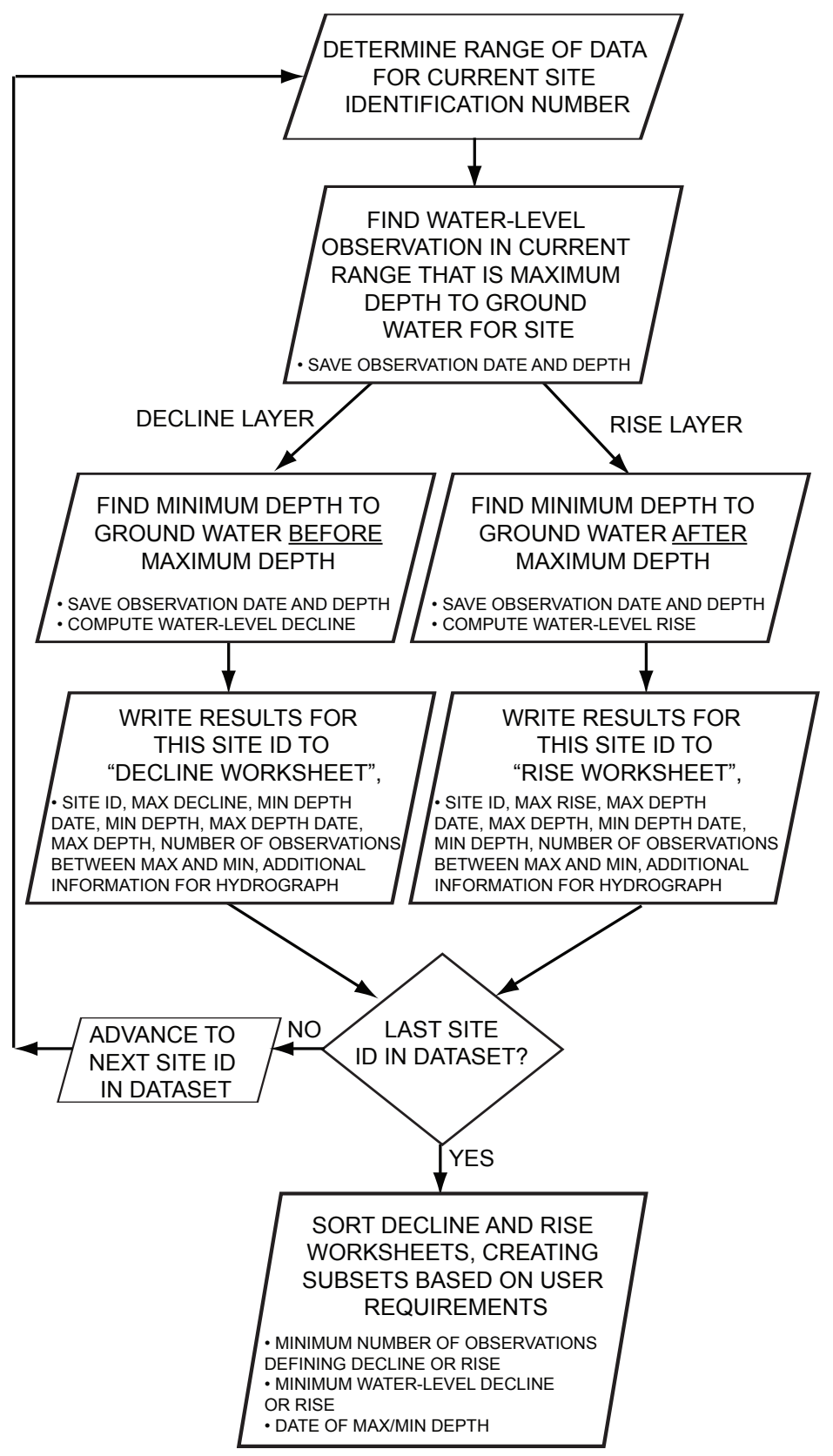

Figure 1. Schematic representation of algorithm for VBA ${ }^{\circledR}$ program that produces ground-water conditions subset of wells experiencing water-level declines and wells experiencing water-level rises.

produced by the preceding program and an output file for projecting the selected wells in a GIS system. Producing custom hydrographs for many of the indicators of ground-water conditions allows for descriptive information to be added to the hydrograph that emphasizes the data used in the interpretation. For the water-level decline and rise conditions, observations used to compute the total decline and rise values are highlighted on the hydrograph and the values themselves are displayed (fig. 2). This allows those interested in further details to see the observations used in determining if a well is included in a declining or rising water-level subset in the context of all available data for the well. 

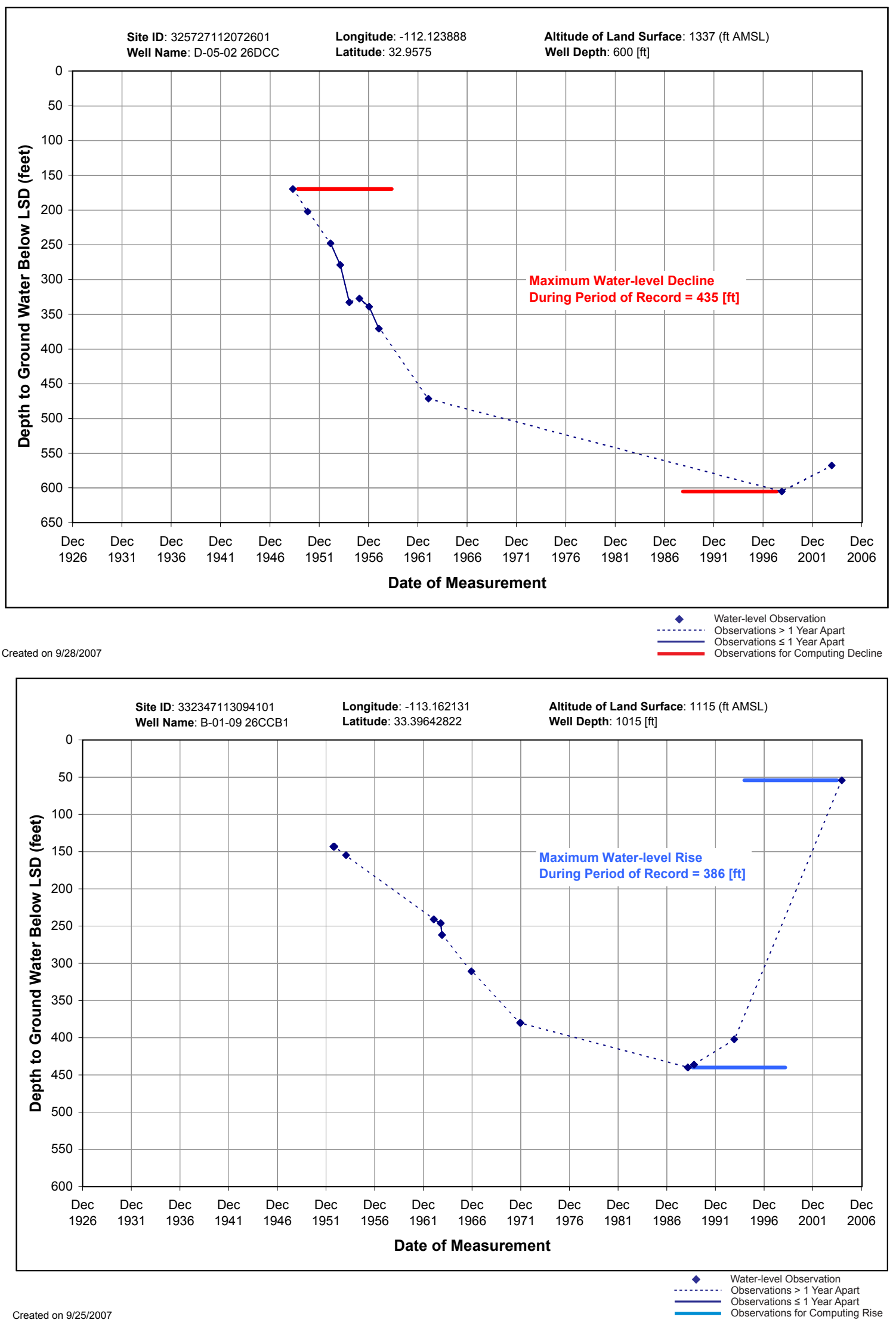

Figure 2. Examples of annotated hydrographs produced for wells experiencing water-level decline (top) and wells experiencing water-level rise (bottom). 
The VBA ${ }^{\circledR}$ program written to produce the decline or rise subsets of data analyzes all observations for each well in the spreadsheet. For a particular well record, the maximum depth to ground water is first identified, followed by the minimum depth to ground water. For the declining water-level subset, the minimum depth to ground water will occur before the maximum depth and may be the first observation in the dataset for a constantly declining water table. The rising water-level subset contains wells with the minimum depth to water occurring after the maximum depth. The maximum depth to water may be the first observation in the dataset for the well. A worksheet is produced containing summary information for each well in the dataset (fig. 3). This information includes the site identification number, the maximum water-level decline or recovery, the dates of observation, and depths of minimum and maximum ground-water levels. Additional information is contained in the summary worksheet for each well that is utilized by the hydrograph-VBA ${ }^{\circledR}$ program to highlight the points of inflection on the hydrograph. The summary worksheet allows the user to see the range of water-level declines and rises for the dataset being analyzed, as well as the number of observations defining the decline or rise. On the basis of this information, the user can decide what subset of the decline or rise wells to display in the GIS. For the alluvial basins analyzed in the Lower Colorado River Basin in Arizona, a minimum water-level decline of 75 feet was used for inclusion in the declining water-level subset and a minimum rise of 50 feet was used for inclusion in the rising water-level subset. For both the declining and rising subsets, at least four observations were required to define the rising or falling water levels. Screening by minimum levels of decline and rise, and by number of observations defining the decline and rise, produces a manageable number of wells in the subsets, eliminating wells with observations that simply oscillate. By providing the dates of the maximum and minimum water-level observations, the user is able to further break the subset of declining or rising wells into time periods of interest by displaying these sites separately in a GIS system. For the analyses in Arizona, the datasets were divided into a "historical" group with waterlevel declines or rises that occurred before 1997 and a "recent" set with declines or rises that continue after that date. Displaying the declines and rises in time-selected groupings allows for temporal information to be conveyed through the GIS system.

A second $\mathrm{VBA}^{\circledR}$ program was created that constructs annotated hydrographs for all of the wells in the summary decline or rise worksheets produced by the first program and writes an output worksheet used in displaying the wells (with links) in a GIS system. This program scans through the list of wells on

\begin{tabular}{|c|c|c|c|c|c|c|c|c|c|c|c|c|c|c|c|c|}
\hline & A & $B$ & C & D & $E$ & $\mathrm{~F}$ & G & $\mathrm{H}$ & 1 & $\mathrm{~J}$ & $\mathrm{~K}$ & $\mathrm{~L}$ & M & N & 0 & $\overline{\hat{\lambda}}$ \\
\hline 1 & Site_ID & $\begin{array}{l}\text { Max_Drawdown_- } \\
\text { Before_Recovery }\end{array}$ & $\begin{array}{l}\text { Min_Depth_ } \\
\text { Date }\end{array}$ & $\begin{array}{l}\text { Min_Depth_To } \\
\text {-GW_Before_ } \\
\text { Recovery }\end{array}$ & pt1x_high & pt2x_high & pt1y_high & pt2y_high & $\begin{array}{l}\text { Max_Depth } \\
\text { _Date }\end{array}$ & $\begin{array}{l}\text { Max_Depth_To_GW_At } \\
\text { _Start_Of_Recovery }\end{array}$ & pt1x_low & pt $2 \times \_$low & pt1y_low & pt2y_low & nObservations & \\
\hline 2 & 334104111542501 & 120.2 & $2 \pi / 1975$ & 582 & $8 / 6 / 1975$ & $2 \pi / 1985$ & 582 & 582 & $11 / 2 / 1999$ & 702.2 & $5 / 6 / 1999$ & $11 / 11989$ & 702.2 & 702.2 & $2 \quad 17$ & \\
\hline 3 & 332950112565701 & 119.05 & $3 / 21 / 1961$ & 186.45 & $9 / 7 / M 961$ & $3 / 22 / 1971$ & 186.45 & 186.45 & $8 / 14 / 2002$ & 305.5 & $2 M 5 / 2002$ & $8 / 13 / 1992$ & 305.5 & 305.5 & 183 & \\
\hline 4 & 334359111563401 & 114.9 & $5 / 1 / 1962$ & 730 & $10 / 28 / 1962$ & $5 / 1 / 1972$ & 730 & 730 & $8 / 19 / 2002$ & 844.9 & $2 / 20 / 2002$ & $8 / 18 / 1992$ & 844.9 & 844.9 & 39 & \\
\hline 5 & 333648112131001 & 240.4 & $10 / 25 / 1938$ & 76.3 & $4 / 23 / 1939$ & $10 / 25 / 1948$ & 76.3 & 76.3 & $10 / 26 / 2001$ & 316.7 & $4 / 29 / 2001$ & $10 / 26 / 1991$ & 316.7 & 316.7 & 43 & \\
\hline 6 & 334218112222701 & 232.6 & $11 / 1 / 1938$ & 180 & $4 / 30 / 1939$ & a $11 / 1 / 1948$ & 180 & 180 & $11 / 3 / 1999$ & 412.6 & $5 / / 1999$ & 9 $11 / 2 / 1989$ & 412.6 & 412.6 & 181 & \\
\hline 7 & 334153112080201 & 212.9 & $11 / 15 / 1948$ & 278.2 & $5 / 14 / 1949$ & $11 / 16 / 1958$ & 278.2 & 278.2 & $10 / 21 / 1997$ & 491.1 & $4 / 24 / 1997$ & $10 / 21 / 1987$ & 491.1 & 491.1 & 24 & \\
\hline 8 & 333817112154801 & 206.98 & $11 / 19 / 952$ & 213.52 & $5 / 18 / 1953$ & 11/20/1962 & 213.52 & 213.52 & $11 / 8 / 2000$ & 420.5 & $5 / 12 / 2000$ & 11/8/1990 & 420.5 & 420.5 & 35 & \\
\hline 9 & 333223112280901 & 166.5 & $2 \pi / 9662$ & 202.8 & $8 / 6 / 1962$ & $2 \quad 2 / 8 / 1972$ & 202.8 & 202.8 & $11 / 1 / 1999$ & 369.3 & $5 / 5 / 1999$ & $10 / 31 / 1989$ & 369.3 & 369.3 & 34 & \\
\hline 10 & 331953111315001 & 138.7 & $2 / 17 / 1979$ & 308.7 & $8 / 16 / 1979$ & $2 / 17 / 1989$ & 308.7 & 308.7 & $11 / \pi / 2000$ & 447.4 & $5 / 11 / 2000$ & $11 / \pi / 1990$ & 447.4 & 447.4 & 20 & \\
\hline 11 & 333723112192501 & 108.33 & $2 / 20 / 962$ & 279.87 & $8 / 19 / 1962$ & 2. $2 / 21 / 1972$ & 279.87 & 279.87 & $10 / 21 / 1997$ & 388.2 & $4 / 24 / 1997$ & $10 / 21 / 1987$ & 388.2 & 388.2 & 9 & \\
\hline 12 & 333607112214501 & 104.8 & $12 / 9 / 1962$ & 344.1 & $6 / 17 / 1963$ & 12/9/1972 & 344.1 & 344.1 & $12 / 1 / 998$ & 448.9 & $6 / 4 / 1998$ & 3 11/30/1988 & 448.9 & 448.9 & 11 & \\
\hline 13 & 334205112163801 & 98.1 & $12 / 0 M 984$ & 293 & $6 / 8 / 1985$ & $12 / 11 / 1994$ & 293 & 293 & $11 / 13 / 2000$ & 391.1 & $5 / 17 / 2000$ & $11 / 13 / 1990$ & 391.1 & 391.1 & 13 & \\
\hline 14 & 333127111544601 & 88.7 & $2 / 1 / 1966$ & 332.2 & $7 / 31 / 1966$ & 5. $2 / 2 / 1976$ & 332.2 & 332.2 & $10 / 30 / 2001$ & 420.9 & $5 / 3 / 2001$ & $10 / 30 / 1991$ & 420.9 & 420.9 & 27 & \\
\hline 15 & 330751112213401 & 79.45 & $3 / 1 / 1962$ & 297.75 & $8 / 28 / 1962$ & $3 / 1 / 1972$ & 297.75 & 297.75 & $11 / 15 / 2000$ & 377.2 & $5 / 19 / 2000$ & $11 / 15 / 1990$ & 377.2 & 377.2 & 33 & \\
\hline 16 & 332843112191601 & 79.4 & $12 / 3 / 4984$ & 88.1 & $6 / 1 / 1985$ & $12 / 4 / 1994$ & 88.1 & 88.1 & $12 / 1 / 1997$ & 167.5 & $6 / 21 / 1997$ & $12 / 18 M 987$ & 167.5 & 167.5 & 6 & \\
\hline 17 & 333146112560801 & 71 & $1 / 12 / 970$ & 260.2 & $7 / 1 / 1970$ & $1 / 13 / 1980$ & 260.2 & 260.2 & $10 / 31 / 2001$ & 331.2 & $5 / 4 / 2001$ & $10 / 31 / 1991$ & 331.2 & 331.2 & 9 & \\
\hline 18 & 331637112291301 & 70.59 & $1 / 1 / 961$ & 145.31 & $6 / 30 / 961$ & $1 / 2 / 1971$ & 145.31 & 145.31 & $11 / 4 / 1997$ & 215.9 & $5 / 8 / 1997$ & 7) $11 / 4 / 1987$ & 215.9 & 215.9 & 25 & \\
\hline 19 & 332308111345001 & 70 & $4 / 11 / 1978$ & 461.8 & $10 / 8 / 1978$ & $4 / 11 / 1988$ & 461.8 & 461.8 & $11 / 5 / 2001$ & 531.8 & $5 / 9 / 2001$ & $11 / 5 / 1991$ & 531.8 & 531.8 & 83 & \\
\hline 20 & 332308111345002 & 67.1 & $4 / 1 / / 978$ & 468.4 & $108 / 1978$ & $4 / 11 / 1988$ & 468.4 & 468.4 & $11 / 5 / 2001$ & 535.5 & $5 / 9 / 2001$ & $11 / 5 / 1991$ & 535.5 & 535.5 & 80 & \\
\hline 21 & 334418112261701 & 63.5 & $2 M 1 / 955$ & 330 & $7 / 31 / 1955$ & $2 M 1 / 965$ & 330 & 330 & $11 / 8 / 2000$ & 393.5 & $5 / 12 / 2000$ & $11 / 8 / 1990$ & 393.5 & 393.5 & 42 & \\
\hline 22 & 333816112154801 & 63.4 & $12 / 20 / 973$ & 352 & $6 / 18 / 1974$ & $+12 / 21 / 1983$ & 352 & 352 & $12 / 5 / 997$ & 415.4 & $6 / 8 / 1997$ & 7) $12 / 5 / 1987$ & 415.4 & 415.4 & 5 & \\
\hline 23 & 333345111360001 & 60.7 & $12 / 21 / 1994$ & 481.3 & $6 / 19 / 1995$ & $12 / 21 / 2004$ & 481.3 & 481.3 & $11 / 22 / 2000$ & 542 & $5 / 26 / 2000$ & $11 / 22 / 1990$ & 542 & 542 & 6 & \\
\hline 24 & 333355112212801 & 55.6 & $12 / 8 / 1984$ & 390.1 & $6 / 16 / 1985$ & 12/19/1994 & 390.1 & 390.1 & $5 / 8 / 1997$ & 445.7 & 11/9/1996 & 5 $5 / 8 / 1987$ & 445.7 & 445.7 & 4 & \\
\hline 25 & 334154112001401 & 53.5 & 3/9/986 & 431.9 & $9 / 15 / 1986$ & 3) $3 / 19 / 1996$ & 431.9 & 431.9 & $11 / 6 / 2001$ & 485.4 & $5 / 10 / 2001$ & $11 / 6 / 1991$ & 485.4 & 485.4 & 15 & \\
\hline 26 & 333539112192301 & 51.2 & $1 / 15 / 985$ & 292.5 & $7 / 44 / 1985$ & 5 $1 / 16 / 1995$ & 292.5 & 292.5 & $11 / 2 / 1999$ & 343.7 & $5 / 6 / 1999$ & $11 / 1 / 1989$ & 343.7 & 343.7 & 17 & \\
\hline 27 & & & & & & & & & & & & & & & & \\
\hline 28 & \multicolumn{16}{|c|}{3 Historical Decline (before 1/M/M997) } \\
\hline 29 & 334109112131201 & 450.95 & $2 / 19 / 1952$ & 256.85 & $8 / 17 / 1952$ & $2 / 19 / 1962$ & 256.85 & 256.85 & $12 / 8 / 1988$ & 707.8 & $6 / 11 / 1988$ & $12 / 8 / 1978$ & 707.8 & 707.8 & 23 & \\
\hline 30 & 331219111434201 & 406.7 & $2 / 25 / 1953$ & 197.3 & $8 / 24 / 1953$ & $2 / 26 / 1963$ & 197.3 & 197.3 & $12 / 1 / 1982$ & 604 & $6 / 4 / 1982$ & $211 / 30 / 1972$ & 604 & 604 & 19 & \\
\hline 31 & 331324111370001 & 368.91 & $1 / 17 / 1949$ & 170.79 & $7 / 16 / 1949$ & $1 / 18 / 1959$ & 170.79 & 170.79 & $6 / 4 / 1986$ & 539.7 & $12 / 6 / 1985$ & $5 \quad 6 / 3 / 1976$ & 539.7 & 539.7 & 5 & \\
\hline 32 & 331410111324401 & 368.06 & $1 / 18 / 1949$ & 207.54 & $7 / 17 / 1949$ & $1 / 19 / 1959$ & 207.54 & 207.54 & $6 / 28 / 1985$ & 575.6 & $12 / 30 / 1984$ & $6 / 28 / 1975$ & 575.6 & 575.6 & 4 & \\
\hline 33 & 331219111322901 & 362.67 & $2 / 18 / 1952$ & 215.73 & $8 / 16 / 1952$ & $2 / 18 / 1962$ & 215.73 & 215.73 & $6 / 27 / 1985$ & 578.4 & $12 / 29 / 1984$ & $6 / 27 / 1975$ & 578.4 & 578.4 & 22 & \\
\hline 34 & 333730112110201 & 357.61 & $4 / 4 / 1946$ & 133.89 & $10 / M 946$ & 5/4/1956 & 133.89 & 133.89 & $6 / 4 / 1975$ & 491.5 & $12 / 6 / 1974$ & $4 \quad 6 / 3 / 965$ & 491.5 & 491.5 & 19 & \\
\hline 35 & 333817112115601 & 353 & $12 / 28 / 1948$ & 168.5 & $6 / 26 / 1949$ & 12/29/1958 & 168.5 & 168.5 & $11 / 30 / 982$ & 521.5 & $6 / 3 / 1982$ & $211 / 29 / 1972$ & 521.5 & 521.5 & 7 & \\
\hline 36 & 331644111373201 & 337.1 & $1 / 11 / 929$ & 117 & $7 / 10 / 1929$ & 1/1/2/939 & 117 & 117 & $6 \pi / 988$ & 454.1 & $12 M 0 / 987$ & 7 $6 \pi / 978$ & 454.1 & 454.1 & 18 & \\
\hline 37 & 334000112173001 & 336.74 & $11 / 3 / 949$ & 174.26 & $5 / 2 / 1950$ & $11 / 4 / 1959$ & 174.26 & 174.26 & 1/4/4991 & 511 & $7 / 8 / 1990$ & $1 / 3 / 1981$ & 511 & 511 & 30 & \\
\hline 38 & 331040111355101 & 329.7 & $8 / M 948$ & 216 & $1 / 28 / 1949$ & $8 / 2 M 958$ & 216 & 216 & $12 / 5 / 1984$ & 545.7 & $6 / 8 / 1984$ & $4 \quad 12 / 5 / 1974$ & 545.7 & 545.7 & 6 & \\
\hline 39 & 331404111414001 & 328.33 & $1 / 15 / 1940$ & 103.17 & $7 / 13 / 1940$ & $1 / 15 / 1950$ & 103.17 & 103.17 & $2 / 9 / 1970$ & 431.5 & $8 / 13 / 1969$ & 9. $2 / 9 / 1960$ & 431.5 & 431.5 & 50 & \\
\hline 40 & 334003112255001 & 326.7 & $10 M / 1939$ & 198 & $3 / 29 / 1940$ & $10 / 1 / 1949$ & 198 & 198 & $11 / 20 / 991$ & 524.7 & $5 / 24 / 1991$ & $111 / 9 / 1981$ & 524.7 & 524.7 & 5 & $v$ \\
\hline
\end{tabular}

Figure 3. Screenshot of example spreadsheet output from VBA ${ }^{\circledR}$ program summarizing wells experiencing water-level decline. 
the summary worksheet, pulls all observations for each well from the original data worksheet, plots the data on $\mathrm{x}-\mathrm{y}$ charts on individual worksheets, and puts highlight bars on each chart indicating which observations were used for the decline or rise calculations (fig. 2). A worksheet is also created that contains the latitude, longitude, site identification number, magnitude of water-level decline or rise, and a link containing the path and filename for each well hydrograph. This worksheet can be read by GIS programs as an xyz input file and used for projecting the location of wells in this layer with linked hydrographs. The magnitude of water-level decline or rise is used to define the color intensity of the symbol representing the locations of wells (figs. 4 and 5). An overview of locations of wells that have experienced declines or rises can then be seen, with further information available on a well hydrograph by selecting the well of interest with the hyperlink tool.

The visual inspection of the hydrograph of each well provides a quality assurance of data for the decline and rise subsets. Although no observations flagged as "pumping" in the database are used in the processing of these subsets, there may be minimum or maximum depth observations found that appear to not be indicative of local ground-water conditions (for example, a sharp decline or rise in water level in a short time period between otherwise fairly stable observations). A third VBA ${ }^{\circledR}$ program was written for processing the wells of the decline and rise subsets as an aid in the correction of hydrographs found to be utilizing possibly erroneous observations as determined by the user during visual inspection. This program requests the new maximum or minimum water-level observation and observation date (determined by the user from visual inspection of the hydrograph) and updates the summary worksheet, the maximum or minimum depth highlight bars, the computed decline or rise, and the associated output worksheet used by the GIS system.

A significant and obvious limitation of the interpretation provided in the declining and rising subsets is that the amount of decline and rise for each well can only be computed from available data. In many instances in the Arizona water-level data analyzed using the methods in this report, the minimum depth to ground water was the first observation in the well's period of record. While water-level decline computed on the basis of this first observation is informative, it does not include any decline in water level in the area that may have occurred before this first recorded observation. Therefore, water-level declines and rises in these subsets should properly be termed "observed declines and rises" to distinguish these measured changes in water level from those that occurred before or after the observations in the well record. Presentation of subsets of data indicating declining or rising water levels does, however, illustrate which areas have been under stress during different time periods and which areas may be responding with increased water levels. By displaying these subsets of declining and rising water levels in a GIS format with linked interpretive hydrographs, information (and not just data) can be made available and understandable on the history of changes in water levels.

\section{Recent Trends in Ground-Water Levels}

Presenting subsets of wells experiencing significant water-level declines or rises during different time periods is an important component of understanding ground-water conditions. However, information on the current trends in water levels may be a better indicator of the current and near-future status of the aquifer system. A method was developed to indicate ground-water conditions by evaluating trends in groundwater levels in recent time periods and presenting these trends spatially to highlight regional conditions. A computer program was written to determine linear water-level trends in recent years on the basis of user-defined criteria. Wells with data achieving a specified goodness of linear fit are then used in a second program that constructs modified Thiessen polygons around each well and writes output files for displaying these polygons in a GIS system. Spatial presentation of these recent trends in water levels provides regional indicators of groundwater conditions and identifies areas having rising, stable, or falling ground-water levels.

\section{Determining Trends in Water-Level Data}

To determine trends in ground-water levels, a FORTRAN program was written that performs a linear regression on a subset of the data determined interactively by user-specified criteria (fig. 6). It is desirable to utilize as many wells as possible in a given area to represent trends in ground-water levels. By including more wells, ground-water conditions in a greater area can be interpreted and more confidence can be placed in conclusions based on similar trends in adjacent areas. However, only wells presenting a definitive trend should be considered in order to avoid misinterpretations based on scattered data. The trend-determination program works with a comma-delimited version of the well and water-level worksheet described previously (table 1). The trend-determination program begins by reading in all data from the worksheet. The user is first prompted for the start and end dates of the time period under investigation. The program sorts through the unique sites in the dataset, counts the number of wells with $\geq 2$ water-level observations in the specified time period and reports this number to the user. The number of wells with less than two observations is also reported. Confirmation of the time period is then requested of the user, with an option to modify the start and/or end dates. The subset of data in the approved time period is saved.

Once the subset of observations in the requested time period has been determined, the user is prompted to select the data in the subset that will be used for trend analysis. Options for this selection are (1) using all water-level observations in the date range (fig. $7 A$ ), (2) using only seasonal data based on user-specified months of the year (fig. 7B), (3) using only observations that occur at the maximum or minimum amplitude of cyclical data (figs. $7 C, D$ ), or (4) using any combination of these subsets of data. Multiple subsets can be 


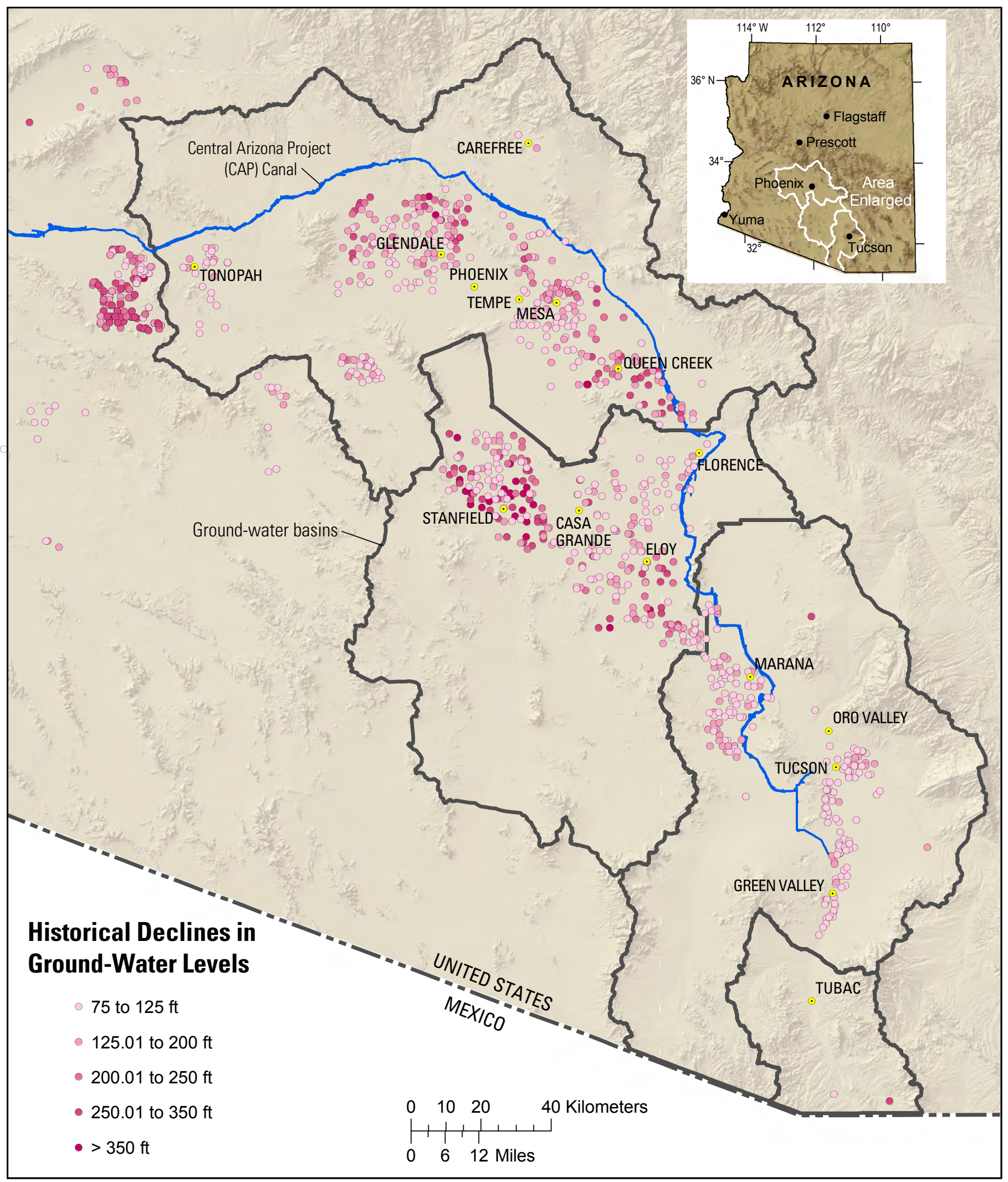

Figure 4. Wells experiencing significant ground-water level decline during historical (pre-1997) time in the most developed basins of south-central Arizona. Well locations are linked to annotated hydrographs in the GIS system. 


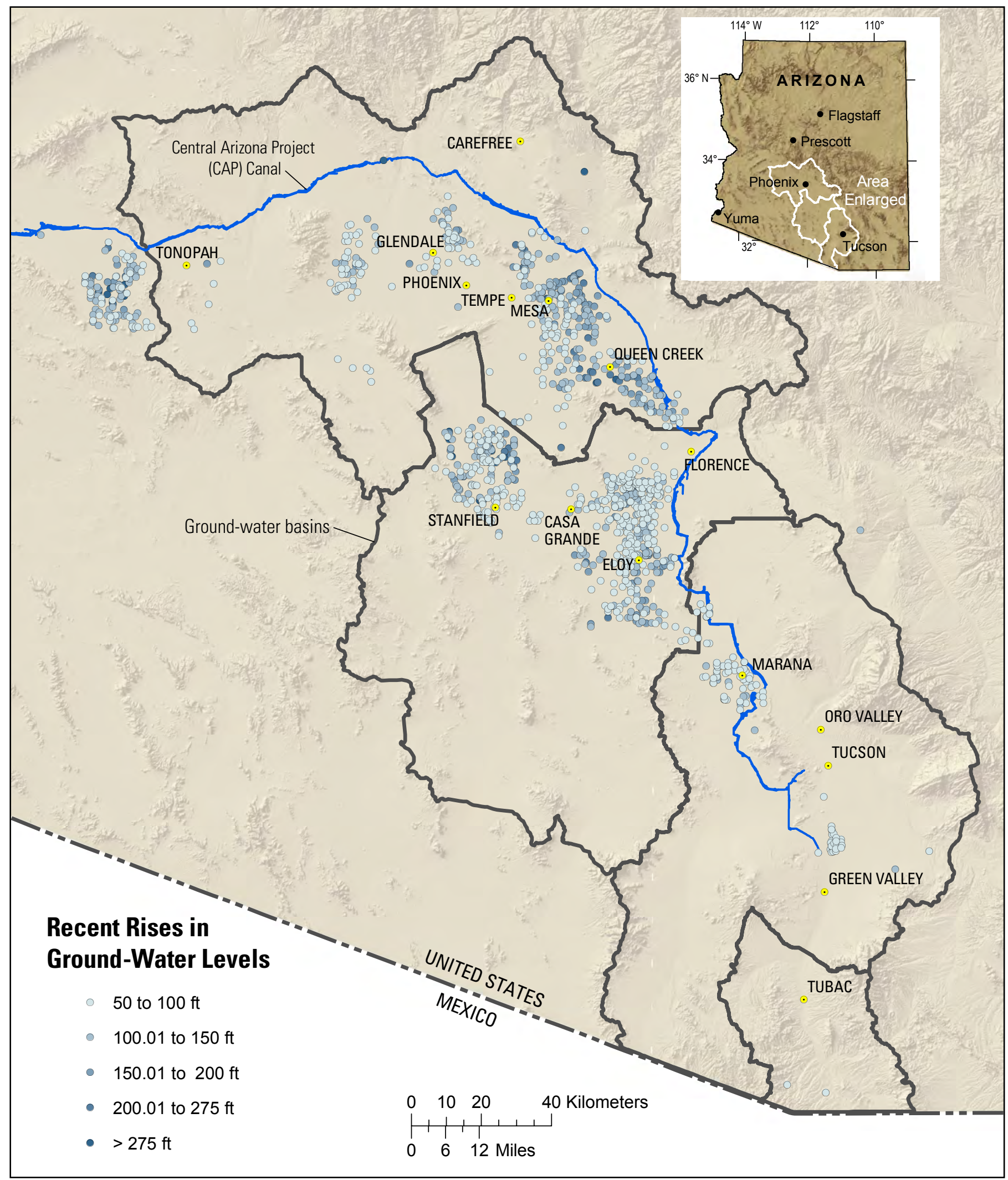

Figure 5. Wells experiencing significant ground-water level rise continuing through recent time (post-1997) in the most developed basins of south-central Arizona. Well locations are linked to annotated hydrographs in the GIS system. 
created by choosing more than one option. The purpose of providing multiple options for the selection of subsets of data is to compute an acceptable linear regression that accurately describes the trend of water levels for as many wells as possible. For infrequently measured water levels, utilizing all data provides the most information and the best possibility of identifying a trend in water-level observations. However, data that are collected more frequently may benefit from analyses of seasonal (specified months) or cyclical (maximum and minimum amplitude) subsets of data (see table 2 for results using example Idaho dataset). If the seasonal data option is selected, the user is prompted to select the months in which observations are to be analyzed. The user is then informed of the number of wells with at least two observations in the given date range in the user-specified months and the number of wells with less than two observations. The user is asked to confirm this choice of months or given the opportunity to modify them. Subsets of the water-level data are saved to appropriate arrays.

Upon choosing the types of data in the date range for trend analysis, the user is prompted for a minimum number of water-level observations for the well to be used in the analysis. Information is reported to the user on the number of wells for each case that have at least the user-specified minimum number of observations and also the number of wells for other values of minimum observations down to two. The user may choose a new minimum or confirm the existing choice. Selecting wells by minimum number of valid measurements allows the user to maximize confidence in the resulting trend information while providing information on tradeoffs between minimum observations and number of wells for which a trend will be computed. For instance, it may be desirable to have at least 10 water-level observations in a 20 -year period for trend analysis, but if there are 3 times the number of wells with at least 5 observations then a compromise may be acceptable. The user may then elect to "bracket" the start and/or end dates of the trend analysis. Bracketing requires that at least one water-level observation be within a user-specified number of months after the start date and/or before the end date for the well to be given further consideration in the trend analysis. The use of bracketing ensures that trends are computed for wells with water-level observations that span the time period under investigation and are not computed for wells with water levels that are grouped around a single point in time.

At this point in the trend-computation algorithm, subset(s) of water-level data have been produced through a process of choosing date range, type of data (all data, seasonal, maximum amplitude, and/or minimum amplitude), minimum number of observations, and possibly start and/or end bracketing. Linear trends are computed on all remaining subsets of data with further screening of data based on user-specified coefficient of determination $\left(\mathrm{R}^{2}\right)$ of the linear fit. To aid in selecting an appropriate minimum $\mathrm{R}^{2}$ for screening, the user is provided with information on the number of remaining wells with linear trends having $\mathrm{R}^{2} \geq 0.25,0.50$, and 0.75 for each of the cases chosen previously. The user is prompted for a minimum coefficient of determination, the program reports the number of wells with linear trends meeting this criterion for each subset of data, and the user is asked to confirm or change this minimum $R^{2}$ value. Once a minimum $R^{2}$ value is selected, the user decides which group will be chosen for output (all data, seasonal, maximum amplitude, and/or minimum amplitude, or any combination of these subsets). The program will output all of the water-level information and well data for each of the cases chosen. If a well appears in more than one subset of data, information on the well from the subset producing the highest coefficient of determination is outputted.

Two output files are produced by the trend-determination program. The first is an input file used by the program described in the next section that creates modified Thiessen polygons to represent spatially the trends in ground-water conditions. The header of this file contains all selection information, including date range, bracketing information, seasonal screening information, minimum number of observations, and minimum goodness of linear fit (fig. 8). This header aids in keeping track of multiple output files for different datasets. Below this header are data for each of the wells in the final selection, including trend information of slope, y-intercept, and $\mathrm{R}^{2}$ of the linear trend of the data; the number of observations used in the trend computation; the name of the subset of data output; and well information of latitude and longitude of the well location, site identification number, well name, well altitude, hole depth, and well depth. The second file outputted by this program contains trend information for each selected well along with all water-level observations and dates used in determining the trend. This file is used by a separate VBA ${ }^{\circledR}$ program that creates hydrographs and highlights the observations used for trend analysis (fig. 9). Creation of hydrographs for the wells used in the trend analyses is useful for linking with the spatial representation of the trend information described in the next section. Visual inspection of hydrographs should be conducted to identify data that should be deleted from the Thiessen input file.

\section{Spatial Representation of Water-Level Trend Information}

Spatial representation of linear-trend point information provides a regional picture of trends in ground-water conditions. The method developed for this tool involves spatial extrapolation of the trend information using the concept of Thiessen (or Voronoi) polygons. Thiessen polygons have been used to analyze spatially distributed data in ecology (individual space per plant or animal), meteorology (areal rainfall estimations from rain gauges), and business (delineation of the marketshed of retail or service nodes), as well as for analysis in other fields (for example, see Mumm, 2005, or Okabe and others, 2000). Briefly, a region of influence for a well is computed with Thiessen polygons by constructing perpendicular bisectors between the well and all other wells in the dataset. The intersections of these bisectors form potential vertices of 


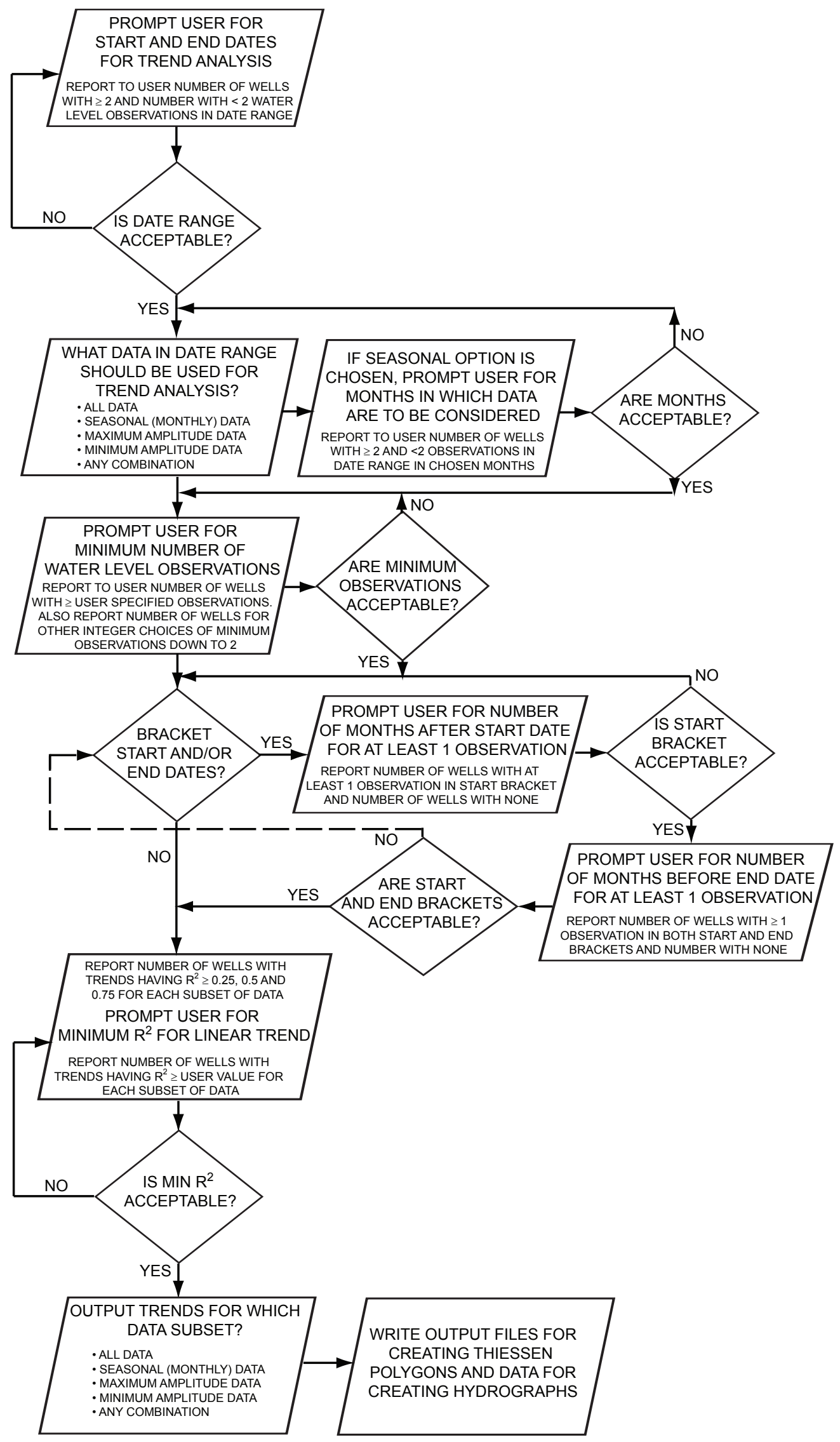

Figure 6. Schematic representation of FORTRAN algorithm for computing trends in ground-water level data. 


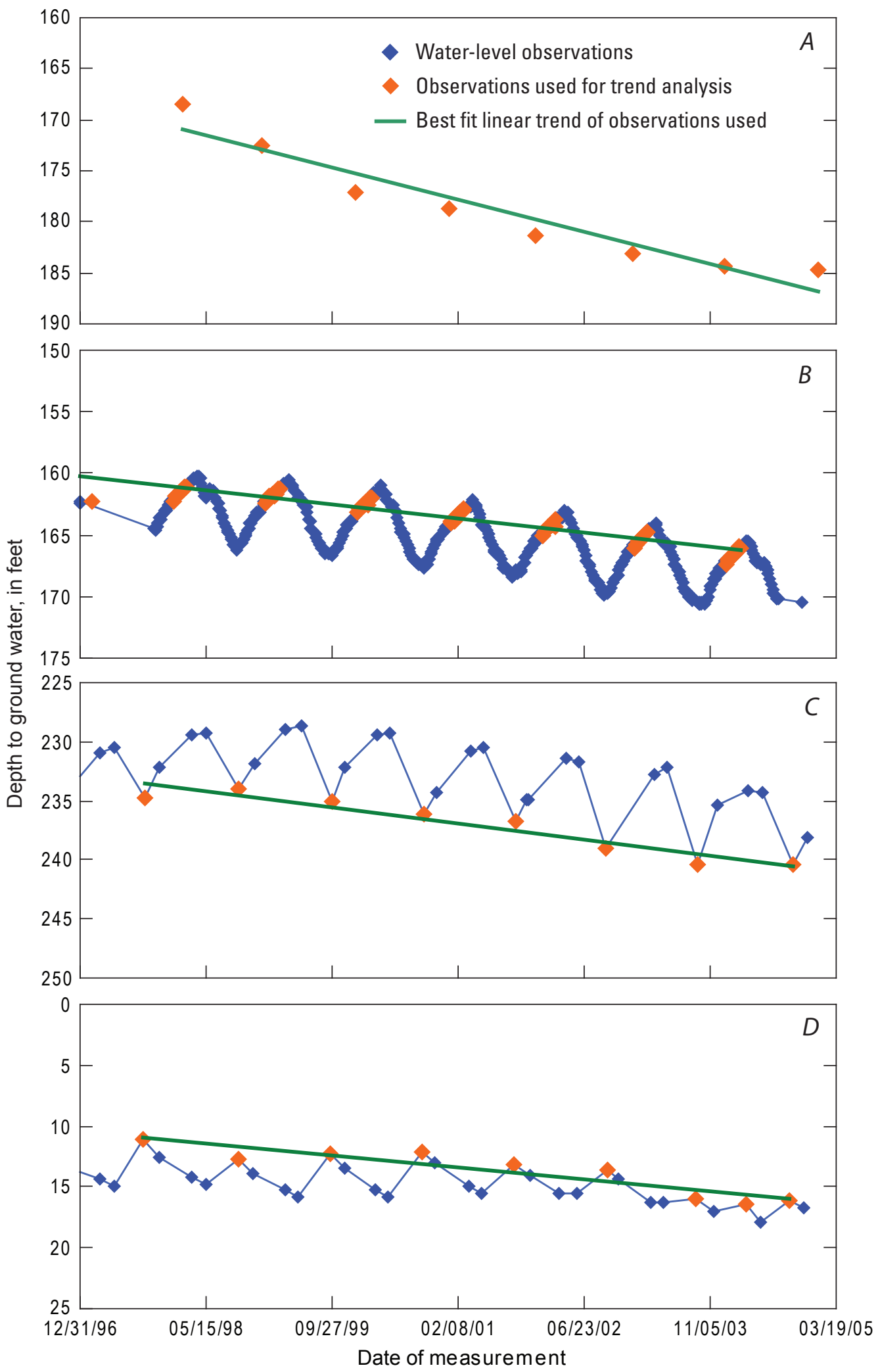

Figure 7. Examples of different subsets of water-level data during a given time period used for trend analyses including $(A)$ all data, $(B)$ seasonal data (here January and February), $(C)$ minimum amplitude data, and $(D)$ maximum amplitude data. 
Table 2. Number of wells from example Idaho dataset with acceptable linear trends in ground-water levels for different subsets of water-level observations analyzed.

[All subsets in this example required a minimum of three observations in the time period from January 1, 1997, to December 31, 2006, and a minimum goodness of linear fit of 0.50 .]

\begin{tabular}{lc}
\hline Subset of water-level observations & $\begin{array}{c}\text { Number of wells in dataset } \\
\text { with acceptable linear } \\
\text { trends in water levels }\end{array}$ \\
\hline All available observations & 339 \\
$\begin{array}{l}\text { Seasonal (January and February } \\
\text { observations) }\end{array}$ & 268 \\
Maximum amplitude observations & 399 \\
Minimum amplitude observations & 388 \\
Best linear fit of all subsets & 616 \\
\hline
\end{tabular}

the polygon, with final vertices being ones closest to the well that form a closed loop. Thiessen polygons are constructed so that any location within a polygon is nearer to that polygon's interior well than to any other well.

A second FORTRAN program was written to construct modified Thiessen polygons for spatial representation of ground-water trends (fig. 10). To construct the polygons around trend wells, a maximum distance of representation for a well is first required. The maximum-distance boundary limits the distance to which the recent trend information will be applied. Spatial data for wells selected by the trend program are then read into arrays. Geographic information for the wells (latitude and longitude in decimal degrees) is translated into a local coordinate system with the southernmost and westernmost well arbitrarily chosen as the datum. Geographic coordinates are translated to local distances in meters from this origin using the great-circle representation of the Earth (see http://www.nationalatlas.gov/articles/mapping/a projections. html). Having local coordinates in meters allows for easy comparison of a vertex distance from a well with the user-specified maximum radius of influence.

After translating coordinates, the program computes Thiessen polygon vertices by selecting the nearest intersections of all perpendicular bisectors between a well and all other wells in the domain. Additional vertices are added along each edge to create a smoother appearance during application of the maximum distance of representation. If a vertex lies further from a well than the user-specified maximum distance of representation, then the vertex is brought to the maximum distance along the line between the well and the vertex, thus creating a modified Thiessen polygon. Once all vertices are computed for all wells, coordinates are translated back to the geographic system, sorted in a clockwise direction, formatted for use with GIS tools, and saved to a polygon coordinates file. An additional file is written that contains trend information, well information, and the file path to the hydrograph with data for each well used to create each polygon. This file is joined with the Thiessen polygon shapefile in the GIS environment as an attribute table. This permits GIS display options, such as categorization of trend areas by shading polygons, as well as hyperlinking between the trend polygons and well hydrographs, allowing users to see additional details of waterlevel observations.

Application of the analysis and display of water-level trends is demonstrated on data for areas in Arizona with the most developed ground-water systems using the following criteria: a time period of interest from January 1, 1997, to December 31, 2006 (the most recent 10-year period at the time); no bracketing of start or end times; a minimum of three observations required during the period of interest; and a goodness of linear fit $\left(\mathrm{R}^{2}\right)$ of at least 0.75 (fig. 11). Well hydrographs were visually inspected before the inclusion of a well in the trend presentation in order to ensure that the computed trend qualitatively represented the trend in recent water levels. Modified Thiessen polygons were constructed for the resulting subset of wells using a maximum radius of representation of $5 \mathrm{~km}$. Three trend categories were chosen for presentation in this figure: areas with water levels declining at a rate of more than 1 foot per year were labeled "falling"; wells with water-level trends between -1 and +1 foot per year were labeled "nearly stable"; and wells with water levels rising at a rate of more than 1 foot per year were labeled "rising".

While the method of computing and presenting trends in ground-water conditions was demonstrated for a recent 10 -year period, other time periods of interest can easily be analyzed as well. For example, there may be interest in trends in water levels since the enactment of pertinent legislation or management decisions, or in trends since the onset of some climatic change such as a drought or increase in rainfall. Indices of falling, stable, or rising water levels used in the demonstration of the method are easy to understand by the general public, but other discretizations of trends could also be presented. For example, highlighting areas whose water levels are falling at a rate faster than some critical value might identify regions approaching acute water challenges. Analyzing water-level observations that occur during certain months of the year (the seasonal selection) or observations of maximum or minimum water levels in a cyclical period of record allows flexibility to answer questions such as: What is the trend in winter water levels? or What is the trend of water levels during the most extreme dry conditions each year?

Presenting ground-water conditions in terms of recent trends may not indicate conditions relative to a time before development, but it does allow analysis of wells without extensive historical records. An analysis of recent trends allows for determination of current status and near-future projections and would be an appropriate index for areas that may not have predevelopment data. In areas that have distinct multiple aquifers with depth, trend analyses will need to be 


\begin{tabular}{|c|c|c|c|c|c|c|c|c|c|c|c|c|c|c|}
\hline & A & B & $\frac{c}{\text { start date }}$ & D & $\begin{array}{l}E \\
\text { NO statt/end }\end{array}$ & $\begin{array}{l}\text { seasonal screening } \\
\text { of }\end{array}$ & $G$ & $\stackrel{H}{H}$ & 1 & J & K & L & M & \\
\hline 1 & 474 & selected wells & $\begin{array}{l}\text { statrt date= } \\
01 / 01 / 1997\end{array}$ & $\begin{array}{l}\text { end date= } \\
12 / 31 / 2006\end{array}$ & $\begin{array}{l}\begin{array}{c}\text { No statt//nd } \\
\text { bracketing }\end{array} \\
\text {. }\end{array}$ & $\begin{array}{l}\text { seasonal screening of of } \\
1.2 \text { moths }\end{array}$ & $\begin{array}{c}\text { min Observations }= \\
3\end{array}$ & $\begin{array}{c}\min R 2 \text { fit } \\
0.500\end{array}$ & & & & & & \\
\hline & & & & & & nobs & Site ID & Well Name & & Hole_Depth & Well Depth & & & \\
\hline 4 & 112.698500 & 42.007420 & -0.89 & -65.2 & 0.84 & 5 & 420027112415201 & $16 \mathrm{~S} 32 \mathrm{E} 27 \mathrm{DAB} 1$ & 455.9 & & 23 & & & \\
\hline 5 & 111.947100 & 42.030480 & -3.10 & -263.6 & 0.76 & 8 & 420150111564701 & 16S 39E $18 \mathrm{CDA} 1$ & 4542.7 & -99999 & 46.2 & $\operatorname{Max}$ & & \\
\hline$\frac{6}{7}$ & 112.954000 & 42.056330 & -1.27 & -70.7 & 0.98 & 10 & 420323112571202 & 16S 30E 09ABB2 & 465.8 & -99999 & 48.5 & All & & \\
\hline & $\begin{array}{l}112.298500 \\
1112714900\end{array}$ & 42.109920 & -0.57 & 79.2 & 0.88 & 3 & 420636112175201 & 15S 35E $22 \mathrm{AAB} 1$ & $\frac{457.5}{504}$ & -99999 & 22.9 & $\operatorname{Max}$ & & \\
\hline$\frac{8}{9}$ & $\begin{array}{l}111.2714400 \\
113.304900\end{array}$ & $\begin{array}{l}42.135630 \\
42.154640\end{array}$ & $\begin{array}{l}1.24 \\
-1.97 \\
\end{array}$ & $\begin{array}{l}344.4 \\
-3255\end{array}$ & 0.96 & $\frac{4}{7}$ & & 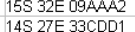 & $\begin{aligned} 504 \\
4715\end{aligned}$ & $\begin{array}{l}-99999 \\
-99999\end{array}$ & $\begin{array}{c}27 \\
1996\end{array}$ & $\operatorname{Max}$ & & \\
\hline 10 & 114.704200 & 42.183240 & $\begin{array}{l}-2.12 \\
-2.12\end{array}$ & -84.3 & 0.68 & 9 & $\begin{array}{l}420171113181501 \\
421100114421201\end{array}$ & $\begin{array}{l}14 S \mathrm{~S} 15 \mathrm{E} 28 \mathrm{BAD1} \\
14 \mathrm{AD2}\end{array}$ & $\begin{array}{l}471.5 \\
4976.1\end{array}$ & $\begin{array}{l}-.999999 \\
-9999 \\
\end{array}$ & $\begin{array}{l}199.6 \\
455\end{array}$ & Max & & \\
\hline & 112.008200 & 42.198810 & -6.48 & -616.9 & 0.94 & 7 & 421156112002701 & $14 \mathrm{~S} 38 \mathrm{E} 15 \mathrm{CDC1}$ & 479.5 & - & $\begin{array}{l}45.5 \\
20\end{array}$ & Max & & \\
\hline & & & & -121.6 & 0.89 & 7 & 421219112184101 & 14S 35E 13DBA1 & 464.1 & -.99999 & 28.9 & Min & & \\
\hline$\frac{13}{14}$ & 111.401800[ & 42.242430 & -0.17 & 3.8 & 0.60 & 4 & 1433111240401 & $13543 E 35 C C D 1$ & 595.5 & -99999 & 50 & Max & & \\
\hline 14 & $111.2790000^{\circ}$ & 42.268260 & -1.17 & -104.1 & 0.69 & 6 & 421602111164001 & 13S $44 \mathrm{E} 26 \mathrm{BAD} 1$ & 597 & -99999 & 17 & Min & & \\
\hline 15 & 114.045700 & 42.299280 & -4.17 & 222.8 & 0.87 & 14 & 421755114024401 & $13 \mathrm{~S} 21 \mathrm{E} 18 \mathrm{BBC} 1$ & 4953.6 & -99999 & 85 & Max & & \\
\hline 16 & 113.891900 & 42.307970 & 7.26 & 857.2 & 0.94 & 4 & 421829113532801 & 13S 22E 08ADD1 & 4436.79 & -99999 & 30 & Max & & \\
\hline & $\begin{array}{l}114.516400 \\
1113374100\end{array}$ & $\begin{array}{l}42.308800 \\
\end{array}$ & 2.75 & 416.2 & & 53 & 421832114305601 & & 474.2 & -99999 & 70 & Ssn & & \\
\hline $\begin{array}{l}18 \\
19\end{array}$ & $\begin{array}{l}113.374100 \\
112596090\end{array}$ & $\begin{array}{r}42.313940 \\
42320750\end{array}$ & $\begin{array}{l}-4.58 \\
-0.045 \\
\end{array}$ & -413.1 & 0.90 & $\frac{7}{16}$ & $\begin{array}{l}421852113222601 \\
42191511253401\end{array}$ & 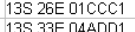 & $\begin{array}{l}4517.6 \\
553.6\end{array}$ & -999999 & $\begin{array}{l}223.16 \\
14575\end{array}$ & Min & & \\
\hline 20 & $\begin{array}{l}112.596000 \\
113.531100\end{array}$ & $\begin{array}{l}42.32560600 \\
42.35860\end{array}$ & $\begin{array}{l}-.0 .45 \\
-.582\end{array}$ & $\begin{array}{r}1.6 \\
-519.3\end{array}$ & 0.91 & $\begin{array}{l}16 \\
7\end{array}$ & 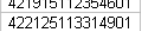 & $\begin{array}{l}135 \\
125 \mathrm{E} \\
25 \mathrm{EAAAA}\end{array}$ & $\begin{array}{l}515.3 \\
535.6\end{array}$ & $\begin{array}{l}-999999 \\
-9999 \\
\end{array}$ & $\begin{array}{l}\begin{array}{l}145.15 \\
177.17\end{array} \\
\end{array}$ & $\begin{array}{l}\text { All } \\
\text { Max }\end{array}$ & & \\
\hline & 113.578000 & 42.401420 & -2.54 & .222 .2 & 0.78 & 8 & 2405113343801 & $12 \mathrm{~S} 25 \mathrm{E} 06 \mathrm{DCCC}$ & 475.5 & & 10226 & Max & & \\
\hline 22 & 113.758300 & 42.416020 & -1.36 & 225.4 & 0.70 & 8 & 2458113452701 & $21 \mathrm{CCD} 2$ & 4271.1 & -.99999 & 412.3 & Ssn & & \\
\hline 23 & 113.911600 & 42.4165 & & 226.1 & & 8 & $501113543901 \mathrm{P}$ & & 4309.7 & -99999 & 63.5 & Max & & \\
\hline 24 & 114.403300 & 42.433250 & -1.01 & -10.1 & 0.74 & 7 & 4226001142409001 & $11517 \mathrm{E} 250002$ & 4138.5 & -99999 & 351.65 & Max & & \\
\hline & 114.268900 & 42.439080 & -1.13 & -11.4 & & 10 & 2621114160501 & $11 \mathrm{~S} 19 \mathrm{E} 30 \mathrm{ADD} 1$ & 4156.79 & -99999 & 21.5 & $\operatorname{Max}$ & & \\
\hline 26 & 113.315200 & $42.444 \mathrm{C}$ & -2.76 & -135.5 & & 8 & & 13S 16E 12DAA1 & & & 247.35 & Ssn & & \\
\hline & $\begin{array}{l}114.051900 \\
1114200500\end{array}$ & & & $\begin{array}{l}-1.7 \\
0359\end{array}$ & & 8 & $\begin{array}{l}422647114030401 \\
4225641411501\end{array}$ & & 425.8 & & 103 & $\operatorname{Max}$ & & \\
\hline 29 & $\begin{array}{l}114.200500 \\
114.268900\end{array}$ & $\begin{array}{l}42.448250 \\
42.451300\end{array}$ & $\begin{array}{l}-5.68 \\
-5.72\end{array}$ & $\begin{array}{l}-355.9 \\
-411.3 \\
\end{array}$ & 0.722 & $\frac{9}{3}$ & $\begin{array}{l}4226541141115901 \\
42270511460501\end{array}$ & $\begin{array}{l}13 S \text { 16E } 120 \mathrm{AA} 1 \\
11 \mathrm{~S} 19 \mathrm{E} 1 \text { 10DAD2 }\end{array}$ & $\begin{array}{c}419 \\
41429\end{array}$ & $\begin{array}{l}-999999 \\
-99999\end{array}$ & $\frac{112}{35}$ & Sin & & \\
\hline 30 & $\begin{array}{l}114.260000 \\
112.149900\end{array}$ & $\begin{array}{l}42.457500 \\
42.472420\end{array}$ & -0.72 & $\begin{array}{l}-417.3 \\
-59.4\end{array}$ & & 9 & $\begin{array}{l}4222010511441600017 \\
42282112085701\end{array}$ & $\begin{array}{l}115 \text { 19E } 190 \mathrm{AU} 2 \\
11 \mathrm{~S} 37 \mathrm{E} \text { 16BBB }\end{array}$ & $\begin{array}{l}4144.29 \\
484.7\end{array}$ & $\begin{array}{l}-9999999 \\
-9999\end{array}$ & 64.65 & Min & & \\
\hline 31. & .114 .672200 & 42.5049 & -0. & 157.3 & & 8 & & & & & 101 & $\operatorname{Max}$ & & \\
\hline & $\begin{array}{l}111.750500 \\
1113353000\end{array}$ & $\begin{array}{l}42.5115 \\
425174\end{array}$ & $\begin{array}{l}-0.37 \\
-156\end{array}$ & 26.6 & & 8 & 3045111450001 & & & & 9 & Min & & \\
\hline$\frac{33}{34}$ & $\begin{array}{l}1.13 .353800 \\
114.108600\end{array}$ & $\begin{array}{l}42.517410 \\
42525300\end{array}$ & $\begin{array}{r}-1.56 \\
-304\end{array}$ & $\begin{array}{l}16.8 \\
44.6\end{array}$ & 0.999 & $\frac{8}{4}$ & $\begin{array}{l}31031132111101 \\
3134114062001\end{array}$ & $\begin{array}{l}13 S 16 E \text { 12DAA1 } \\
10 S 20 \mathrm{E} 2 \mathrm{BCCC1}\end{array}$ & $\begin{array}{l}4478.6 \\
41821\end{array}$ & $\begin{array}{l}-.999999 \\
.9999\end{array}$ & $\begin{array}{l}30.1 \\
735\end{array}$ & Sn & & \\
\hline & 114.009100 & $\begin{array}{l}42.5290080 \\
42.5200\end{array}$ & $\begin{array}{r}-3.84 \\
-2.86\end{array}$ & 25.9 & & 8 & 3145114003001 & $10 \mathrm{~S} 21 \mathrm{E} 28 \mathrm{BCB} 1$ & 4157.2 & $\begin{array}{l}-99999 \\
-99999\end{array}$ & 60.3 & Min & & \\
\hline 36 & 113.951600 & 42.532970 & -1.29 & 144.8 & & 7 & & & & & & $\operatorname{Max}$ & & \\
\hline & $\begin{array}{l}113.907200 \\
11323000\end{array}$ & $\begin{array}{l}42.534910 \\
153650\end{array}$ & $\begin{array}{r}-1.49 \\
173\end{array}$ & 105 & & 10 & & & 4149.5 & -99999 & 56.1 & Max & & \\
\hline $\begin{array}{l}38 \\
39\end{array}$ & $\begin{array}{l}1.13 .334900 \\
114.435800\end{array}$ & $\begin{array}{l}42.536850 \\
42545020\end{array}$ & $\begin{array}{r}-1.73 \\
-114\end{array}$ & -26.7 & 0.611 & $\begin{array}{l}3 \\
13\end{array}$ & $\begin{array}{l}423213113200301 \\
443255114260001\end{array}$ & $\begin{array}{l}\text { 10S 27E 19DAA1 } \\
\text { 10S 17E 114CCD }\end{array}$ & $\begin{array}{r}478 \\
378\end{array}$ & $\begin{array}{l}-.9999999 \\
-99999\end{array}$ & $\begin{array}{l}0 \\
1154\end{array}$ & $\begin{array}{l}\text { All } \\
\text { Max }\end{array}$ & & \\
\hline 40 & 112.270200 & 42.562970 & $\begin{array}{l}-1.14 \\
-0.97\end{array}$ & -20.3 & & 10 & & & & - -999999 & 0 & Min & & \\
\hline 41 & 115.010300 & & -4.90 & -151.2 & & 9 & & & & & 687.86 & & & \\
\hline 42 & 113.8530 & 42.572 & -0.14 & 70.1 & 0.58 & 7 & & & & & 11.5 & Max & & \\
\hline 43 & $\begin{array}{l}-111.813800 \\
-1144930300\end{array}$ & $\begin{array}{r}42.575750 \\
4257890\end{array}$ & -1.38 & $\begin{array}{l}-80.3 \\
1107\end{array}$ & 0.95 & $\frac{7}{3}$ & $\begin{array}{l}423433111484701 \\
423441453201\end{array}$ & 10S 40E 08BBA1 & $\begin{array}{l}5477.1 \\
33725\end{array}$ & -99999 & 30 & Max & & \\
\hline 44 & $\begin{array}{l}1.14 .893100 \\
111808500\end{array}$ & $\begin{array}{l}42.578790 \\
42.584360\end{array}$ & $\begin{array}{l}-1.39 \\
-2.07\end{array}$ & - 121.2 & 0.94 & & $\begin{array}{r}42344441144533201 \\
42350411482801\end{array}$ & $\begin{array}{l}10 S 13 E 020 C D 1 \\
10 S 40 E \text { E } 5 B D D 1\end{array}$ & $\begin{array}{l}3 / 2.5 \\
550\end{array}$ & $\begin{array}{l}-9999999 \\
-99999\end{array}$ & 208 & Min. & & \\
\hline & & (2) 601070 & & & 070 & & & กIS $22 \mathrm{~F}$ З3AПA1 & 1197 ₹9 & .999999 & $25 \%$ & & & \\
\hline
\end{tabular}

Figure 8. Screenshot of example output of trend-computation program with header indicating selection choices.

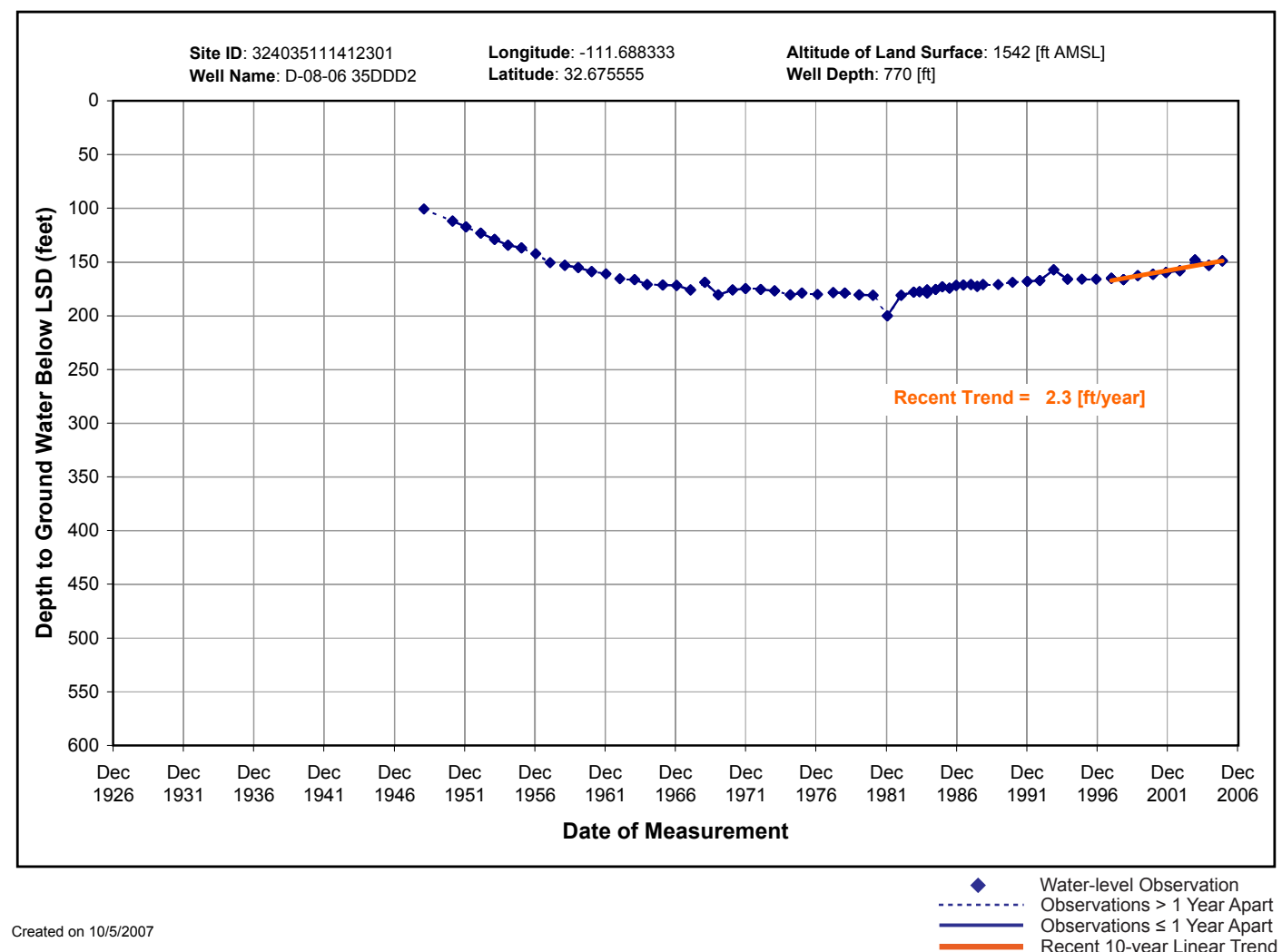

Figure 9. Annotated hydrograph produced during the recent trends in ground-water levels analysis of ground-water conditions. 


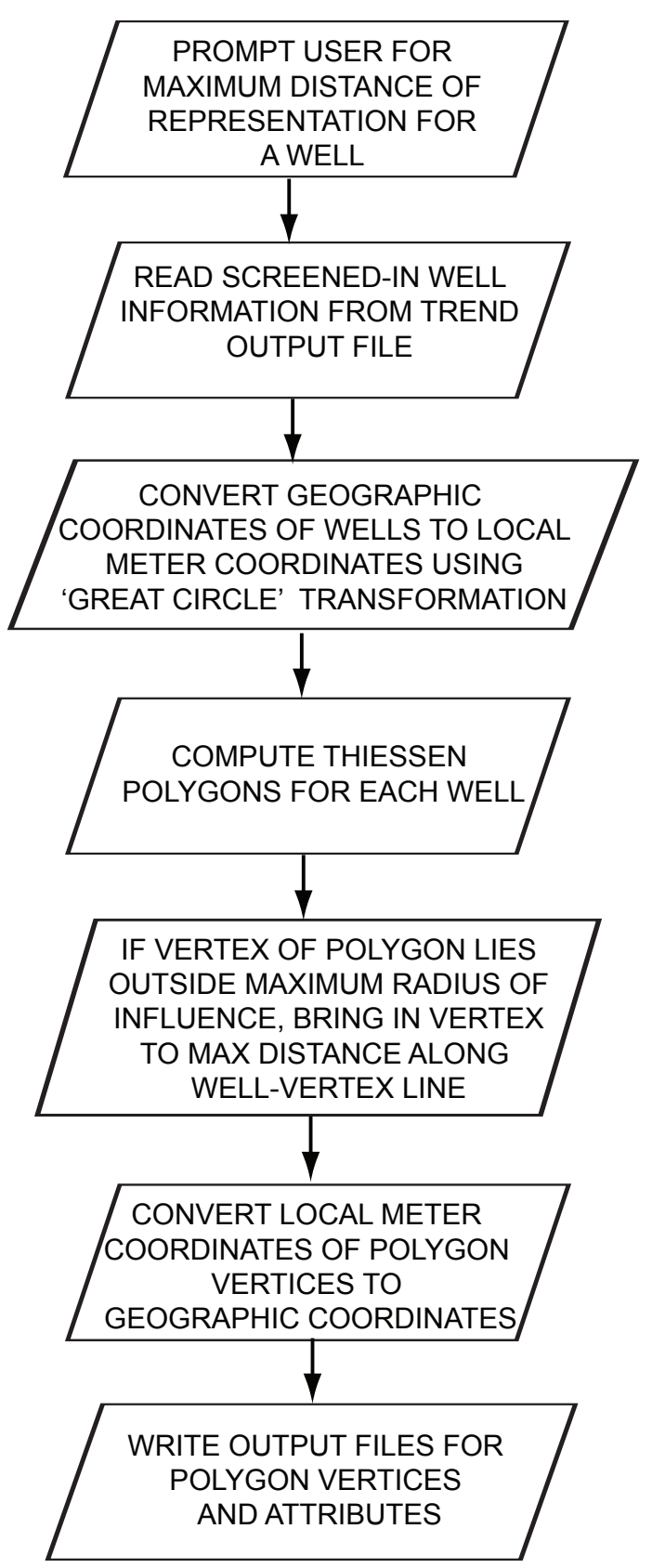

Figure 10. Schematic representation of FORTRAN algorithm for computing modified Thiessen polygons of selected wells for spatial representation of waterlevel trends. performed on groups of wells that screen individual hydrogeologic units. Limitations of the method stem from issues with the areal representation of the trend from each well. The selection of a maximum distance of representation for a well is left to the user's judgment of hydrologic conditions in the area of interest. However, the maximum distance is often only utilized to define the trend area for isolated wells or wells at the perimeter of clusters. Additionally, the trend method does not limit trend areas where they might intersect non-aquifer materials such as exposed bedrock of mountains. This could be rectified by clipping the trend layer using a coverage of geologic materials in a GIS system.

\section{Wells With Long-Term Records}

Long-term changes in ground-water levels may be caused by both human and climate-induced influences. In areas where ground water has been heavily developed for agricultural use, consistent water-level declines may be seen over decades. Changes in water management practices, such as the importation of surface water from areas outside the basin, may also affect aquifers and contribute to stabilization or increases in ground-water levels over time. Wells that tap aquifers in direct hydraulic connection with perennial or intermittent streams or rivers may record changes in water levels that indicate the effects of these surface-water systems and their associated riparian vegetation. Observations of water levels in aquifers in remote, undeveloped areas may indicate the system response to climate changes. In each of these cases as well as many others, it may be advantageous to see evidence of the condition of ground water over as long a period of time as is possible in an area of interest. To aid in the understanding of long-term changes in ground-water conditions, an indicator of ground-water conditions for wells with long-term records was created. Creation of this indicator is facilitated by the use of two VBA ${ }^{\circledR}$ programs written to provide summary information on the periods of records for wells in a dataset and to produce hydrographs and an output file for use in a GIS system based on user-specified criteria of period length and number of observations.

Although a subset of all data from all wells could be created for any basin of interest, it is important to balance the level of effort of producing this indicator subset (and quality-assuring the resulting hydrographs) with the additional information that may or may not be gained. With a focus on the long-term conditions of water levels in a basin, it is desirable to have the subset contain many wells that have long records with datasets as complete as possible. Depending on the history of development for a basin, the time period that constitutes "long term" may vary. A program was written that analyzes the period of record for each well in a dataset and presents summary information on the tradeoffs between the record start date, record end date, and number of observations in a record versus the number of wells that would meet these criteria. The program creates a summary worksheet that contains each unique site identification number in the dataset 
along with the date of the site's first and last observation and the total number of water-level observations for the well. This list of period-of-record information for all wells in the dataset is then summarized by the program in matrices. For several values of minimum number of observations, a matrix is created comparing the number of wells with certain combinations of start/end observation dates. A two-dimensional surface chart graphically presents the same information (fig. 12). From the matrix and chart summary information, the user can decide on what choice of record start date, most recent observation, and minimum number of observations best represents the long-term conditions of the basin of interest and can see how many wells will be represented by these choices. A second VBA ${ }^{\circledR}$ program creates hydrographs and an input file for the GIS system based on user-defined minimum number of observations, earliest observation cutoff date, and latest observation cutoff date. This program scans the dataset for wells that meet these criteria, produces graphs of the water-level observations over time (fig. 13), and creates a worksheet containing the longitude, latitude, site identification number, and well name of each well. Also included in the output worksheet are the number of observations in the well record, the start and end dates of the observations, and the link to the hydrograph for the well. This worksheet can be input into a GIS system as an xyz input file to display the location of these wells. The duration of the period of record of water-level observations for the wells is used to color each well location (fig. 14). Locations of wells with long-term records can then be visualized on basin maps with hydrograph and well information available by selecting the well of interest with the hyperlink tool.

While the aforementioned programs are capable of analyzing very large datasets (such as those for an entire State) for information on long-term ground-water records, it may be beneficial to analyze simultaneously water-level data from smaller groups of basins that have experienced similar historical development patterns. As an example, for some areas in southern Arizona records extending back 25 to 35 years may be sufficient to capture the human-induced changes in water levels, while other areas may need records extending back to pre-World War II time periods or beyond. For the purpose of calibrating ground-water flow models, this analysis and output may also be useful in selecting wells that span a time period of interest and have been frequently measured.

\section{Recent Depth to Ground Water}

A simple yet informative subset of information on ground-water conditions is provided by visualization of the recent depth to ground water in wells. In areas not serviced by water providers, homeowners, realtors, and potential home and land buyers have an interest in knowing the depth from land surface to ground water in their area. Additionally, water providers, farmers, the mining industry, and others might want to know how the depth to ground water varies in their local area and regionally. $\mathrm{A} \mathrm{VBA}{ }^{\circledR}$ program was written that utilizes existing water-level datasets to produce an input file to display in a GIS system the location of wells and the most recent depth to ground water based on a user-defined "recent" date. To illustrate the results of this program, an interactive map service was developed for Arizona that shows this information in a graphical format http://montezuma.wr.usgs.gov/website azgwconditions ).

The definition of what is considered a recent water-level observation may vary in different regions. Ideally, water levels in all wells would be measured very frequently and the most recent observation, subject to some quality assurance standards, would be selected. Because wells in some areas are observed more frequently than in other areas, however, a balance must be achieved between presenting as many wells as possible and the elapsed time since the most recent observation for these wells. The inclusion of more wells helps maximize the area showing the locations of the recent-observation wells (and minimize the potential for users to erroneously extrapolate existing data to areas where there is no current information). Using observations that are too out of date in order to include as many wells as possible, however, may introduce errors in understanding current conditions. The $\mathrm{VBA}^{\circledR}$ program developed to create the subset of wells for the current depth to ground water first analyzes all water-level observations for each well in a dataset and provides the user with summary information to aid in selecting the recent-observation cutoff date. The total number of wells with at least one water-level observation after each year from 2000 through 2007 is presented in a dialog box. The user is then prompted for the recent-observation cutoff date, and a worksheet is produced containing the latitude, longitude, site identification number, well depth, most recent observation date, and most recent water-level depth for wells measured on or after this date. This worksheet can be input as an xyz file into a GIS system for displaying the location of wells with recent observations. Coloration of the well location by groups of depth to ground water provides a visual overview of current ground-water conditions (fig 15). A small pop-up window can also be produced that displays the site identification number, most recent water-level observation and date, and well depth (if available) for wells selected with the hyperlink tool.

Possible limitations to information provided in the indicator of recent depth to ground water result from the impracticability of quality-assuring all recent observations and the potential for misinterpretation of the data presented. Owing to the large number of wells included in the recent depth to ground water subset, it is not feasible to view the most recent water-level observation for each well in the context of other well data to ensure that it is reasonable. For example, there are more than 6,000 wells with a water-level observation on or after January 1, 2004, in the alluvial basin study in Arizona. In order to utilize only measurements that were indicative of natural ground-water levels, any observation flagged as dry, injection, nearby injection, plugged, 


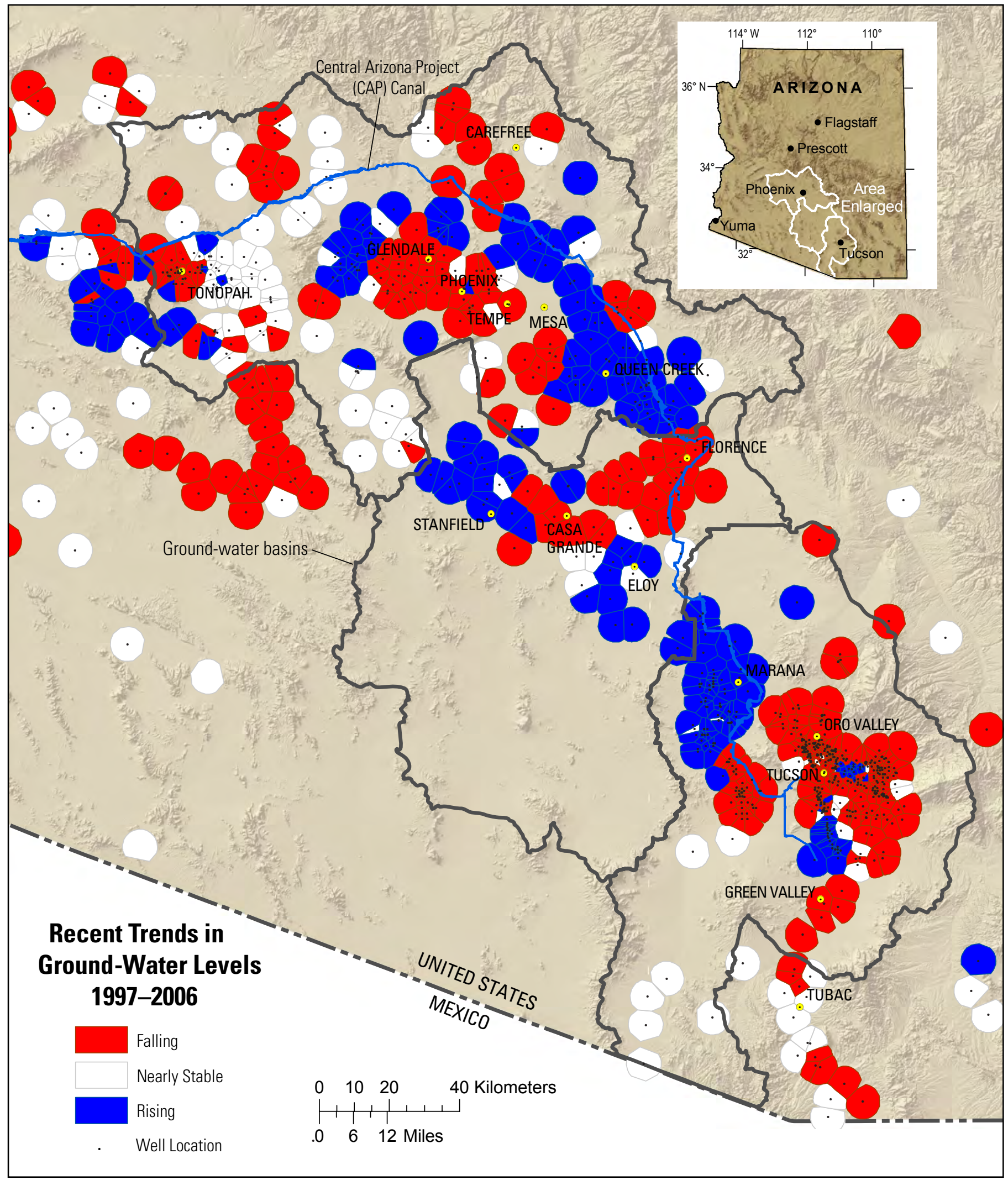

Figure 11. Trends in ground-water levels for the 10-year period from 1997 through 2006 for the most developed basins in south-central Arizona. Trend areas are linked to annotated hydrographs in the GIS system. 


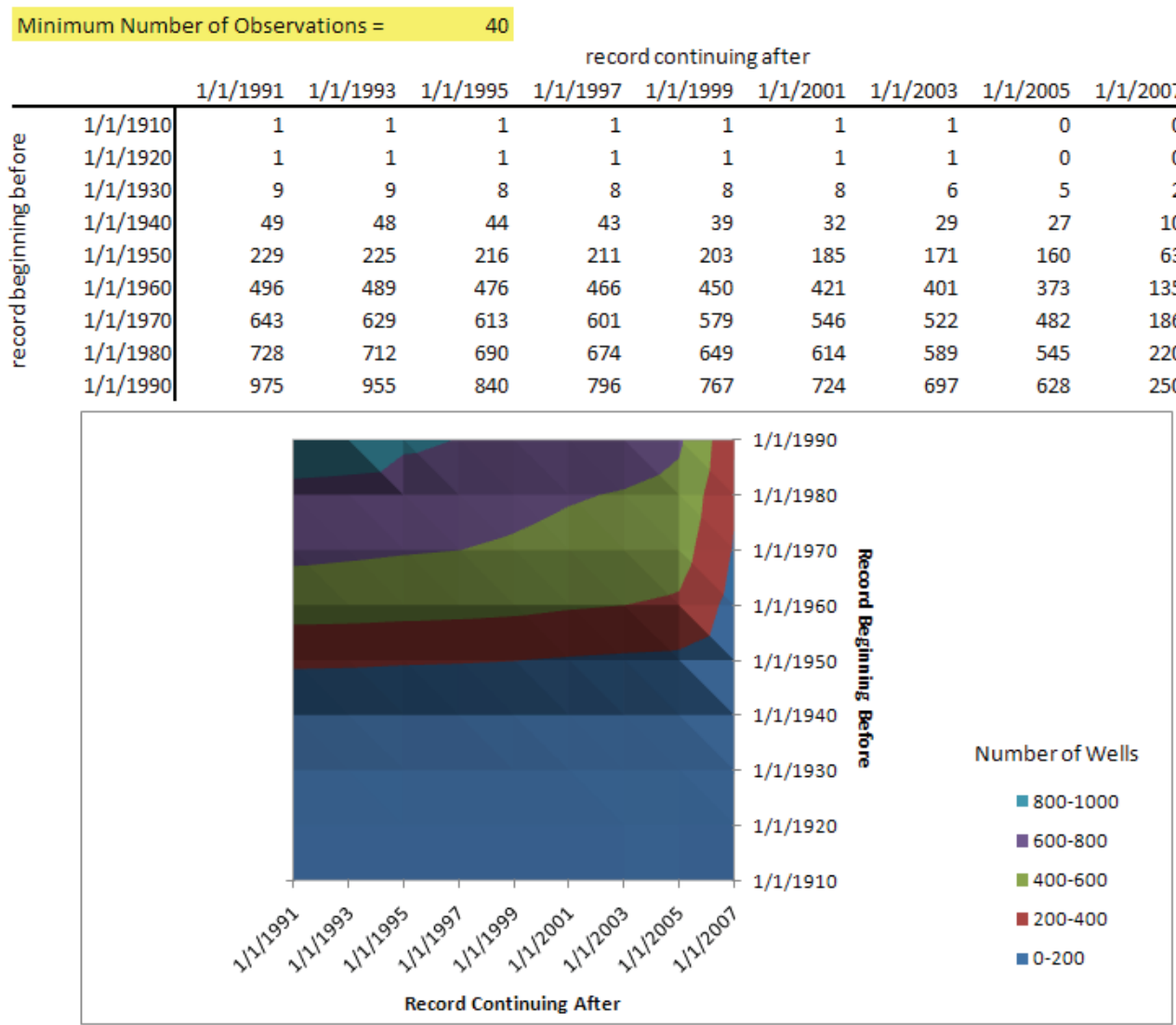

Minimum Number of Observations = 20 record continuing after

\begin{tabular}{|c|c|c|c|c|c|c|c|c|c|c|}
\hline & & $1 / 1 / 1991$ & $1 / 1 / 1993$ & $1 / 1 / 1995$ & $1 / 1 / 1997$ & $1 / 1 / 1999$ & $1 / 1 / 2001$ & $1 / 1 / 2003$ & $1 / 1 / 2005$ & $1 / 1 / 2007$ \\
\hline \multirow{9}{*}{ 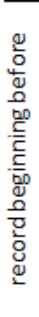 } & $1 / 1 / 1910$ & 1 & 1 & 1 & 1 & 1 & 1 & 1 & 0 & 0 \\
\hline & $1 / 1 / 1920$ & 4 & 2 & 1 & 1 & 1 & 1 & 1 & 0 & 0 \\
\hline & $1 / 1 / 1930$ & 17 & 15 & 12 & 12 & 11 & 11 & 6 & 5 & 2 \\
\hline & $1 / 1 / 1940$ & 71 & 67 & 61 & 59 & 54 & 44 & 36 & 34 & 13 \\
\hline & $1 / 1 / 1950$ & 389 & 381 & 365 & 349 & 324 & 290 & 251 & 228 & 83 \\
\hline & $1 / 1 / 1960$ & 965 & 945 & 910 & 878 & 824 & 768 & 708 & 634 & 188 \\
\hline & $1 / 1 / 1970$ & 1363 & 1327 & 1278 & 1243 & 1169 & 1098 & 1023 & 921 & 269 \\
\hline & $1 / 1 / 1980$ & 1643 & 1602 & 1542 & 1502 & 1417 & 1342 & 1254 & 1138 & 364 \\
\hline & $1 / 1 / 1990$ & 2219 & 2167 & 1985 & 1909 & 1809 & 1721 & 1630 & 1470 & 457 \\
\hline
\end{tabular}

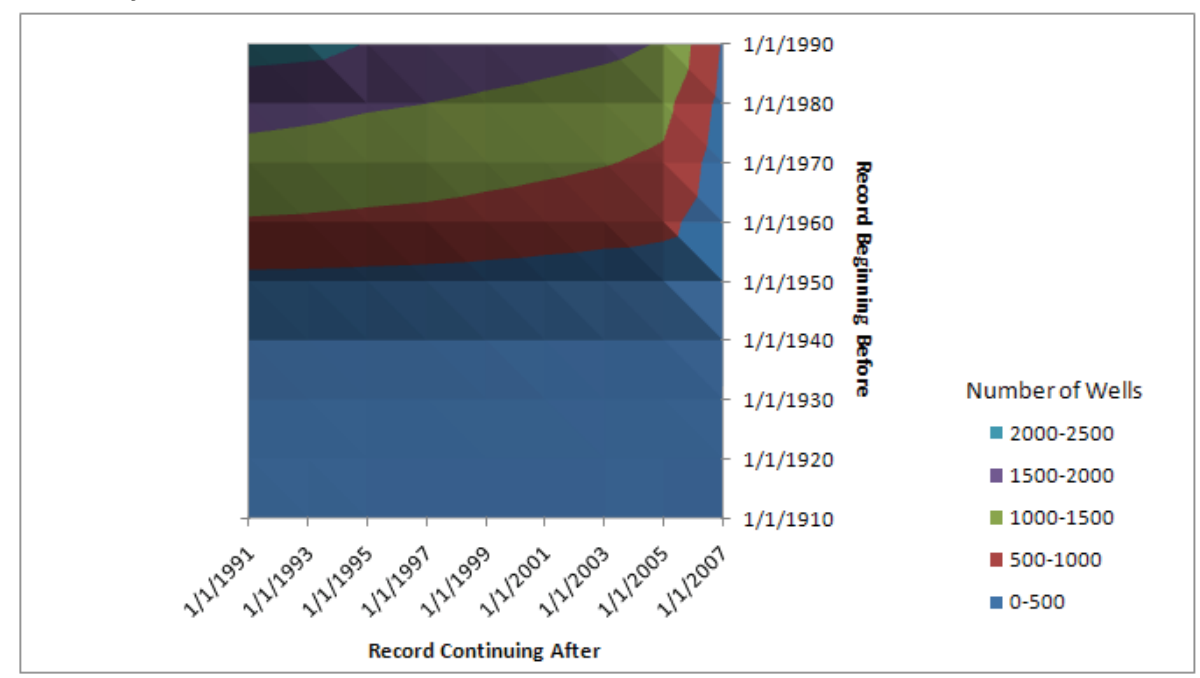

Figure 12. Portion of example output in Microsoft ${ }^{\circledR}$ Exce $^{\circledR}$ spreadsheet of $\mathrm{VBA}{ }^{\circledR}$ program written to provide information on time span and frequency of ground-water level observations to aid in selecting wells for inclusion in "Wells with Long-Term Records" layer. 


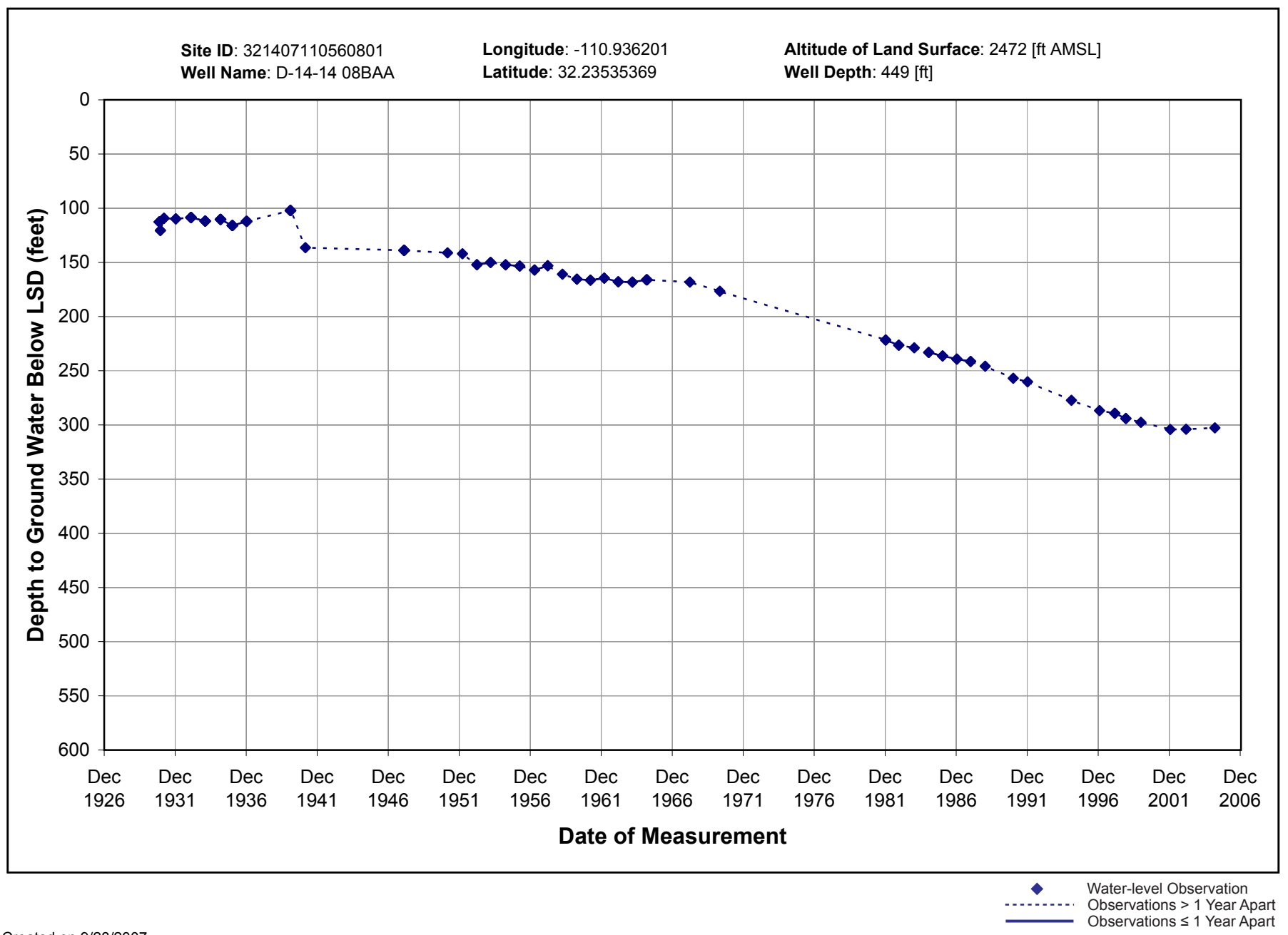

Created on $9 / 28 / 2007$

Figure 13. Example of a hydrograph produced for the "Wells with Long-Term Records" layer of ground-water conditions.

obstructed, pumping, recently pumping, nearby pumping, nearby recently pumping, or well destroyed was not used in the layer. At times, however, data are input incorrectly into databases, either through measurement error or simply mistaken entry (for example, $201 \mathrm{ft}$ when 20.1 was meant). These data may or may not be indicated with any of the flags described above and therefore may present misleading information about the depth to ground water. Additionally, depth to ground water in a well, especially near mountain pediments, may represent only local perched conditions. Attempts to infer depth to ground water some distance from these perched wells may lead to erroneous conclusions.

\section{Summary and Conclusions}

Ground water is the source of drinking water for 50 percent of the population in the United States and as much as 90 percent of the population in rural areas, especially in the southwestern United States (Anderson and Woolsey, 2005). The dependence of domestic use and irrigation upon ground water makes it a highly valuable natural resource. Unlike surface-water indicators such as stage or discharge, groundwater conditions may be more difficult to assess and present. Individual ground-water levels in wells are an illustrative measure of an aquifer system, but these point data do not give a good sense of the regional scale of conditions. Additionally, changes in ground-water conditions may involve time scales ranging from days to many years, depending on recharge, soil properties, and depth to the water table. The lack of an easily identifiable ground-water property indicative of current conditions and inclusive of differing time scales makes the presentation of ground-water conditions a challenging task, particularly on a regional basis. Publicly available tools utilizing easy to understand ground-water information are needed to improve the value of existing datasets. Methods were developed to explore ways of utilizing existing water-level databases for the analysis and presentation of ground-water conditions. Computer software was written to use existing water-level data and aid in creating different indicators of ground-water conditions to display in a GIS system. Several subsets of information covering different time periods and different aspects of 


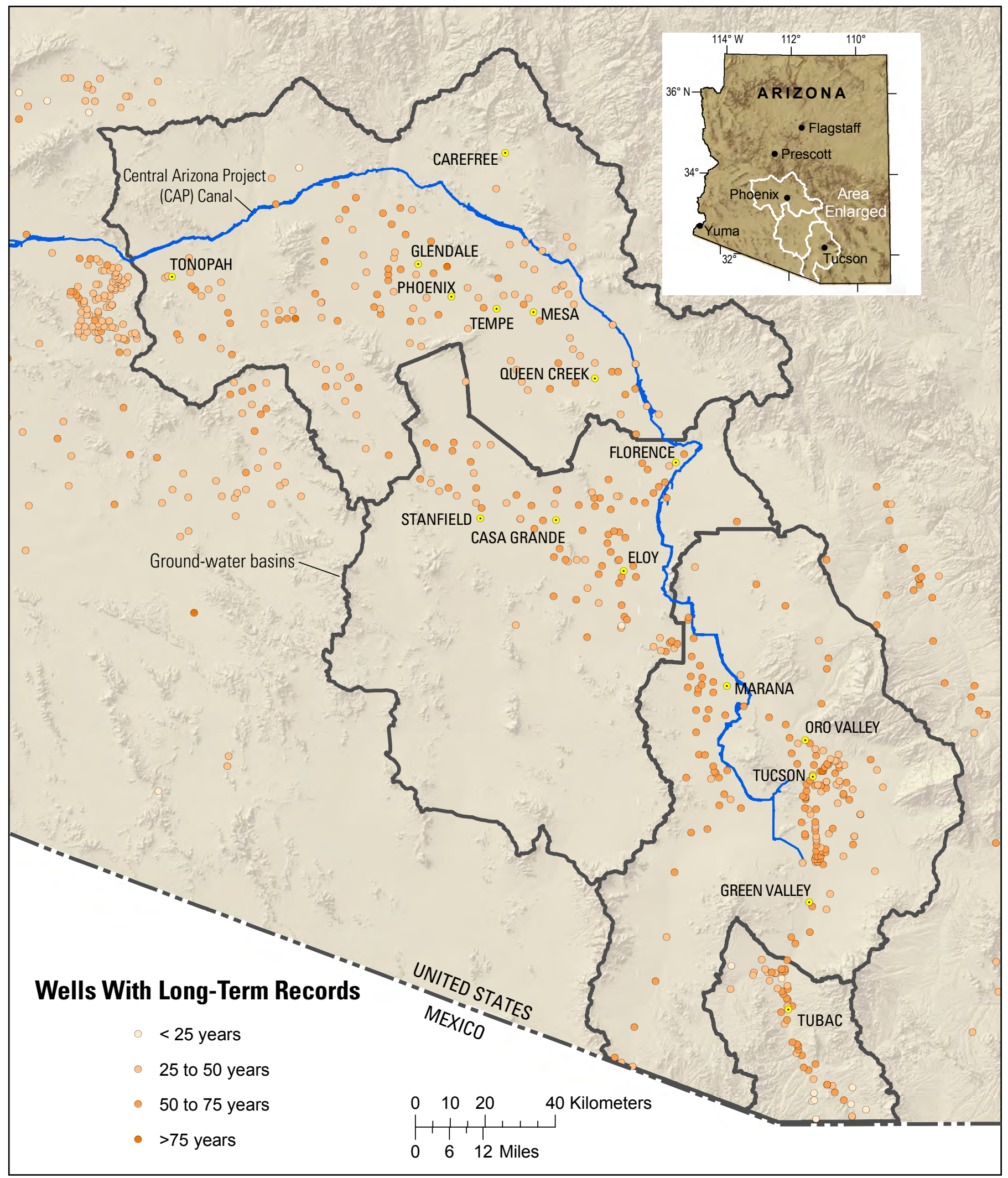

Figure 14. Wells with long-term records in the most developed basins of south-central Arizona. Well locations are linked to annotated hydrographs in the GIS system. 


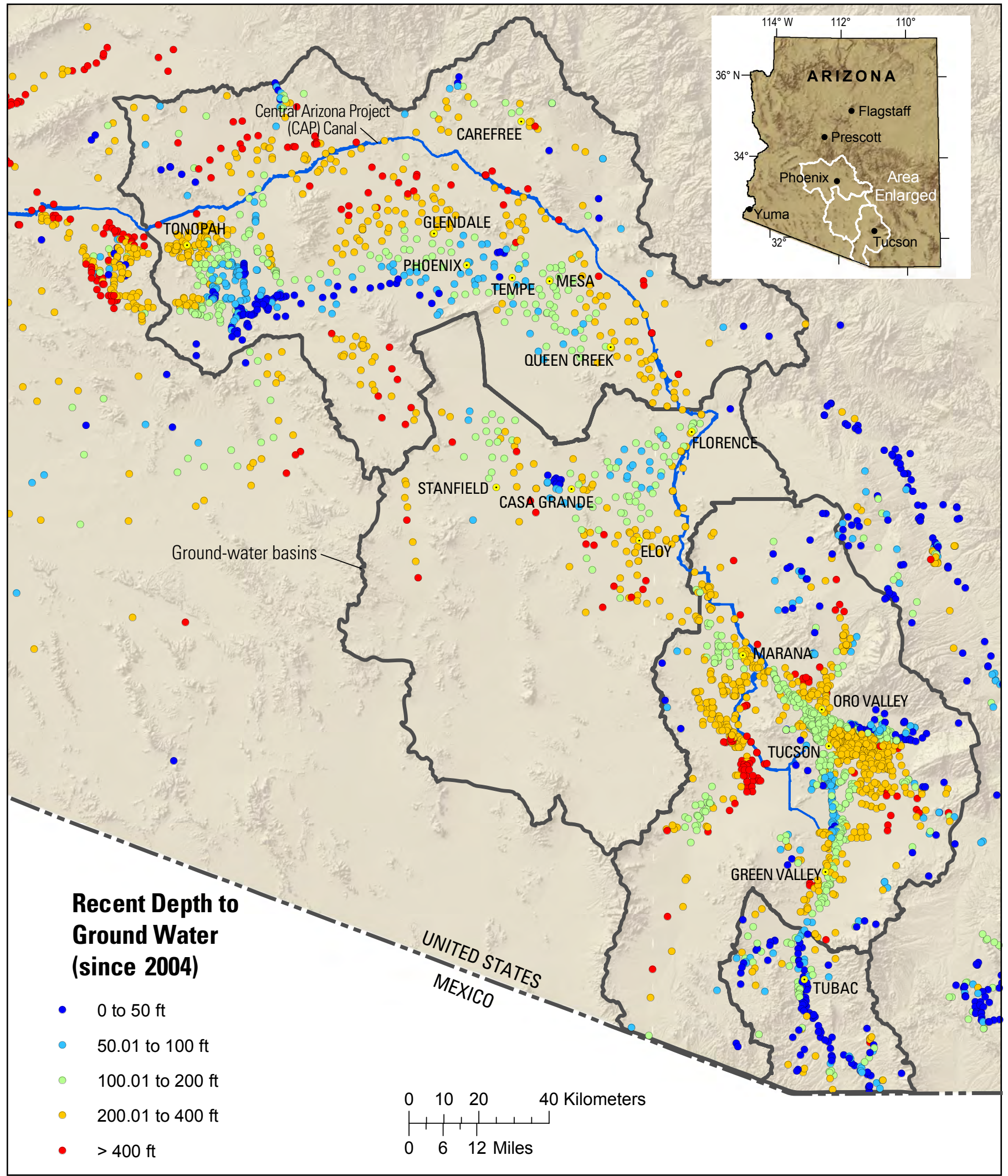

Figure 15. Recent observations of depth to ground water (since 2004) in the most developed basins of south-central Arizona. 
ground-water conditions are described and examples presented in a GIS system using data from the most developed areas of Arizona. Subsets of wells with water-level declines give an indication of how aquifer systems have been depleted, both historically (before 1997) and continuing until present (since 1997). Layers of wells with water-level rises indicate areas that may have recovered, in either past or current times. Longterm well records present information over the longest period available for the basins and may exhibit effects of development, management, and climate. A new method of recent trend analysis provides a depiction of areas whose water levels appear to be improving, worsening, or holding steady on the basis of the most recent 10-year record. Trend analyses take into account anthropogenic and climatic impacts on aquifers and allow insight into systems where lengthy historical records are unavailable. A simple but informative analysis and presentation of recent depth to ground water in wells provides easy to understand information on local aquifer conditions. The use of consistent coloration across basins in the GIS system to identify levels of information for each subset of wells provides a visual overview of the region. The intensity of colored symbols can be used to highlight areas that are under stress or responding to management actions. For most indicators, additional details are provided through annotated hydrographs that are hyperlinked to well locations in the GIS system. This presents an opportunity to highlight aspects of a well's hydrograph that provide evidence of the interpretation being emphasized in the indicator of ground-water conditions.

The methods presented highlight the importance of frequent and consistent collection of ground-water level data (also, see Taylor and Alley, 2001). More information is available from frequently collected datasets, such as seasonal trends, than is available from more sparsely collected data. Additionally, it is important for ground-water levels to be monitored in rural areas in which significant development is planned in order to have a sufficient baseline from which to compare future impacts on the aquifer system. Groundwater levels are one good measure of the health of an aquifer system. Publicly available tools that are easy to understand are needed to make use of these valuable datasets. Application on a regional scale of the methods and indicators developed here would provide a consistent picture of ground-water conditions across the southwestern United States that is currently lacking. Regionally consistent indicators of ground-water conditions are of growing importance in an area where rapidly increasing population and potential climate change put increased stress on this valuable but unseen resource. Though estimates of recharge and ground-water extractions, and forecasts based on ground-water models are useful, ultimately only "facts under the ground" are evidence that ground-water resources are being managed in a sustainable manner.

\section{References Cited}

Anderson, Mark T., and Woolsey, Lloyd H., Jr., 2005, Water availability for the Western United States - key scientific challenges: U.S. Geological Survey Circular 1261, 85 p. http://pubs.er.usgs.gov/usgspubs/cir/cir1261, accessed October 28, 2008].

Anderson, T.W., 1995, Summary of the Southwest Alluvial Basins, Regional Aquifer-System Analysis, south-central Arizona and parts of adjacent States: U.S. Geological Survey Professional Paper 1406-A, 33 p.

Mumm, M., 2005, Voronoi diagrams: Montana Mathematics Enthusiast, v. 1, no. 2, p. 44-55.

Okabe, A., Boots, B., Sugihara, K., and Chiu, S.N., 2000, Spatial tessellations; concepts and applications of Voronoi diagrams (2nd ed.) Hoboken, N.J., John Wiley, 696 p.

Taylor, C.J., and Alley, W.M., 2001, Ground-water-level monitoring and the importance of long-term water-level data: U.S. Geological Survey Circular 1217, 68 p. hhttp:// pubs.er.usgs.gov/usgspubs/cir/cir1217, accessed October 28, 2008].

Tillman, Fred D., Leake, Stanley A., Flynn, Marilyn E., Cordova, Jeffrey T., and Schonauer, Kurt T., 2007, An online interactive map service for displaying ground-water conditions in Arizona: U.S. Geological Survey Open-File Report 2007-1436, 16 p. [http://pubs.usgs.gov/of/2007/1436/, accessed October 28, 2008].

U.S. Geological Survey, 1984, National water summary 1983 -hydrologic events and issues: U.S. Geological Survey Water-Supply Paper 2250, 243 p. [http://pubs.er.usgs.gov usgspubs/wsp/wsp2250, accessed October 28, 2008]. 
This page left intentionally blank. 


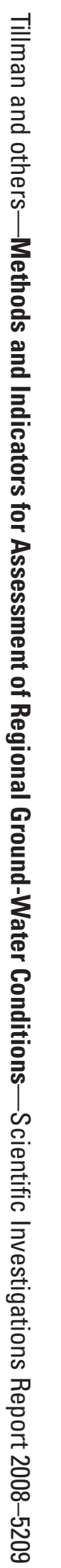

